\title{
Influence of tumors on protective anti-tumor immunity and the effects of irradiation
}

\author{
Gemma A. Foulds ${ }^{1,2+}$, Jürgen Radons ${ }^{3+}$, Mira Kreuzer ${ }^{1}$, Gabriele Multhoff ${ }^{2,4}$ and Alan G. Pockley ${ }^{5 *}$ \\ 1 Department of Oncology, The Medical School, The University of Sheffield, Sheffield, UK \\ ${ }^{2}$ Department of Radiation Oncology, Klinikum rechts der Isar, Technische Universität München, Munich, Germany \\ ${ }^{3}$ multimmune $\mathrm{GmbH}$, Munich, Germany \\ ${ }^{4}$ Clinical Cooperation Group - Innate Immunity in Tumor Biology, Helmholtz Zentrum München, Munich, Germany \\ ${ }^{5}$ John van Geest Cancer Research Centre, Nottingham Trent University, Nottingham, UK
}

\section{Edited by:}

Udo S. Gaipl, University Hosptial

Erlangen, Germany

\section{Reviewed by:}

Angelo A. Manfredi, Vita Salute

San Raffaele University, Italy

Stephen M. Todryk, Northumbria

University, UK

*Correspondence:

Alan G. Pockley, John van Geest

Cancer Research Centre,

Nottingham Trent University,

Clifton Campus, Nottingham,

NG11 8NS, UK.

e-mail: graham.pockley@ntu.ac.uk

these authors equally contributed to this work.
Innate and adaptive immunity plays important roles in the development and progression of cancer and it is becoming apparent that tumors can influence the induction of potentially protective responses in a number of ways. The prevalence of immunoregulatory $T$ cell populations in the circulation and tumors of patients with cancer is increased and the presence of these cells appears to present a major barrier to the induction of tumor immunity. One aspect of tumor-mediated immunoregulation which has received comparatively little attention is that which is directed toward natural killer (NK) cells, although evidence that the phenotype and function of NK cell populations are modified in patients with cancer is accumulating. Although the precise mechanisms underlying these localized and systemic immunoregulatory effects remain unclear, tumor-derived factors appear, in part at least, to be involved. The effects could be manifested by an altered function and/or via an influence on the migratory properties of individual cell subsets. A better insight into endogenous immunoregulatory mechanisms and the capacity of tumors to modify the phenotype and function of innate and adaptive immune cells might assist the development of new immunotherapeutic approaches and improve the management of patients with cancer. This article reviews current knowledge relating to the influence of tumors on protective anti-tumor immunity and considers the potential influence that radiation-induced effects might have on the prevalence, phenotype, and function of innate and adaptive immune cells in patients with cancer.

Keywords: tumor immunity, T cells, NK cells, tumor microenvironment, immunoregulation

\section{INTRODUCTION}

For many years, the paradigm on which the majority of immunotherapeutic approaches for the treatment of cancer has been based, is that adaptive immune responses to tumors are similar to those that are induced in the generation of immunity to infectious pathogens. Although this is, in part at least, the case, a fundamental difference is that responses induced by infectious pathogens are driven by exogenous ("foreign") proteins/molecules, whereas those to tumors must be induced by endogenous ("self") proteins. Although not all tumor antigens are "self" antigens (e.g., EBV antigens, mutated p53), the majority are. For effective immunity, it is therefore necessary to overcome the well-developed capacity of the immune system to regulate responses to self-antigens and tissues.

Tumors can produce immunosuppressive factors such as IL-10, TGF- $\beta$, and vascular endothelial growth factor (VEGF). Tumor-derived cytokines such as IL-10 and TGF- $\beta$ might protect against the development of anti-tumor immunity by influencing the functional capacity of antigen presenting cells (APCs) such as dendritic cells (DCs), and by promoting the generation/differentiation/expansion of immunoregulatory $\mathrm{T}$ cell populations which have the capacity to control and prevent immune responses (Ghiringhelli et al., 2005b; Liu et al., 2007; Mahnke et al., 2007a; Biollaz et al., 2009; Conroy et al., 2012; Multhoff and Radons, 2012). The biology of different immunoregulatory $\mathrm{T}$ cell populations and the functional significance of tumorassociated immunoregulatory $\mathrm{T}$ cells have recently been reviewed (Sakaguchi, 2011; Shevach, 2011; Facciabene et al., 2012; Savage et al., 2013). The net result is a complex relationship between tumors and elements of the protective immune system which has profound influences on the progression and treatment of cancer. It is on the influence of tumors on innate and adaptive immunity by tumors that this article focusses.

\section{IMMUNOREGULATORY T CELLS}

It is now known that thymic deletion of potentially self-reactive $\mathrm{T}$ cells cannot explain the lack of immune responsiveness to selftissues and antigens, as the normal $\mathrm{T}$ cell repertoire includes low affinity $\mathrm{T}$ cells that are reactive against a number of self-peptides. Mechanisms that are capable of controlling the development of immune responses to self-antigens in the periphery must therefore be present. Over the last few years an anti-inflammatory activity has been shown to segregate, in part at least, into a naturally occurring $\mathrm{CD} 4^{+} \mathrm{T}$ cell subset which constitutively expresses 
the $\alpha$ chain of the IL-2 receptor (CD25) (Shevach, 2002; Gavin and Rudensky, 2003; Wood and Sakaguchi, 2003; Lee et al., 2004; Waldmann et al., 2004).

In addition to CD25, these cells also express other antigens including the intracellular transcription factor forkhead box $\mathrm{p} 3$ (Foxp3) (Sakaguchi, 2004), glucocorticoid-induced TNF receptor family-related gene (GITR), the immunoregulatory antigen CTLA-4, neuropilin-1 (Bruder et al., 2004) and, in the case of humans, low cell surface levels of CD127 (Liu et al., 2006b; Seddiki et al., 2006). The depletion or absence of these cells triggers autoimmune destruction of a variety of tissues (Asano et al., 1996; Suri-Payer et al., 1998; McHugh and Shevach, 2002). Although a multitude of immunoregulatory $\mathrm{T}$ and $\mathrm{B}$ cell populations have, and are, being discovered and reported upon, $\mathrm{CD} 4{ }^{+} \mathrm{CD} 25^{\text {high }}$ Treg cells are regarded as being intimately involved in the governance of peripheral self-tolerance (Shevach, 2002, 2011; Nelson, 2004; Sakaguchi, 2004, 2011; Facciabene et al., 2012; Savage et al., 2013).

$\mathrm{CD} 4{ }^{+} \mathrm{CD} 25^{\text {high }}$ Treg cells develop in the thymus and represent $5-10 \%$ of the peripheral CD $4^{+} \mathrm{T}$ cell compartment. Although the expression of Foxp 3 is currently accepted as being the most effective marker of Treg cells in mice and humans (Graca, 2005), there is evidence that some Foxp3 negative cells can be suppressive, and Foxp3 is not therefore a definitive marker for Treg cells (Gavin et al., 2007; Curiel, 2007a; Wan and Flavell, 2007). The suppressive effects of naturally-occurring Treg cells are mediated via relatively far-reaching soluble factors and more intimate cell-cell contact, as well as direct cytotoxic effects on effector cell populations (Schmetterer et al., 2012). These cells are also key regulators of anti-tumor immunity (Facciabene et al., 2012; Lindau et al., 2013; Savage et al., 2013).

According to Savage et al. (2013), the biology of tumorassociated Treg cells involves two developmental pathways: (1) the recognition of self-antigen by developing thymocytes within the thymus leads to the development of naturally-occurring Foxp $3^{+}$ Treg (nTreg) cells and (2), naïve $\mathrm{CD} 4^{+} \mathrm{T}$ cells recognize a tumorassociated or tumor-specific antigen at extrathymic sites and, after being activated, develop into an inducible Foxp $3^{+}$Treg cell (iTreg or $\operatorname{Tr} 1$ ) under a variety of conditions that facilitate/enable tumor immune evasion. These conditions include not only antigen presentation under sub-immunogenic or non-inflammatory conditions, but also chronic inflammation and infections. The observed selective accumulation of Treg cells in the tumor microenvironment suggests that this process can also be driven by tumors.

As hypothesized by Adema and colleagues (Jacobs et al., 2012), four non-mutually exclusive mechanisms can account for the accumulation of Treg cells in the tumor microenvironment: (1) Chemokine secretion induces the selective migration and retention of Treg cells that constitutively express high levels of CCR4 (CCL22, CCL2). (2) Secretion of antiinflammatory mediators such as TGF- $\beta$ and indoleamine 2,3dioxygenase (IDO) converts conventional (naïve) $\mathrm{T}$ cells to Treg cells, either directly or via the actions of antigenpresenting cells; (3) A selective survival advantage of Treg cells over other tumor-infiltrating lymphocytes occurs when negative costimulatory signals selectively influence effector $\mathrm{T}$ cells (PD-L1, FasL). Treg cells also induce receptor-mediated or cytotoxin-mediated Teff cell depletion; (4) tumor-derived immunosuppressive factors such as IL-10 and TGF- $\beta$ promote the expansion of nTreg cells and the de novo generation of iTreg cells.

The different origins of iTreg cells (non-inflammatory, inflammatory) results in distinct properties of these cells which include differential stabilities (Bilate and Lafaille, 2012). iTreg cells are also generated during homeostasis of the gut and in cancer, although some cancers favor the expansion of nTreg cells. Both pathways converge in the tumor environment and this leads to context-dependent Treg cell functions such as the promotion of metastasis and angiogenesis, as well as the limitation of inflammation and blockage of anti-tumor immunity in response to inflammatory conditions (tissue/organspecific) and the tumor microenvironment, respectively. The suppressive effect of nTreg cells is mediated via cell contactdependent mechanisms such as granzyme B/perforin and Fas/FasL (Jonuleit et al., 2001). In contrast, iTreg cells mediate suppression in a cell contact-independent manner (Roncarolo et al., 2006; Bergmann et al., 2008; Mandapathil et al., 2010).

\section{IMIMUNOREGULATORY T CELLS AND ANTI-TUMOR IMMUNITY}

As stated above, a wealth of historical and more recent evidence now suggests that $\mathrm{CD} 4^{+} \mathrm{CD} 25^{\text {high }}$ Treg cell populations influence the presence, induction, and maintenance of protective anti-tumor immunity (Raimondi et al., 2007; Facciabene et al., 2012; Lindau et al., 2013; Savage et al., 2013), and their association with the progression of malignant disease has been highlighted by a number of observations (Table $\mathbf{1}$ ).

These cells present a significant barrier to the induction of tumor immunity (Raimondi et al., 2007; Facciabene et al., 2012; Lindau et al., 2013; Savage et al., 2013), and reducing their numbers and/or function is therefore likely to be of therapeutic potential. The evidence that the depletion of CD $4^{+} \mathrm{CD} 25^{\text {high }}$ Treg cells enhances the capacity to induce cellular and humoral immunity to Her- 2 which is expressed on primary and metastatic breast cancer cells (Fulton et al., 2006) confirms the importance of these cells and highlights the importance of improving our understanding of the influence of the breast tumor microenvironment on protective innate and adaptive anti-tumor immunity.

It is also important to appreciate that other immunoregulatory $\mathrm{T}$ cells such as the adaptive or inducible populations (iTreg) are phenotypically and functionally different to the population discussed above and resistant to apoptosis or oncological therapies (Whiteside, 2012). The potent capacity of these cells to suppress effector $\mathrm{T}$ cell function involves immunosuppressive cytokines such as TGF- $\beta$, IL-10, prostaglandin $\mathrm{E}_{2}$, and adenosine that can be produced by solid tumors and/or Treg cells themselves (Erdman et al., 2003; Roncarolo et al., 2006; Bergmann et al., 2008; Mandapathil et al., 2010; Conroy et al., 2012). As mentioned before, differentiation of naïve $\mathrm{CD} 4^{+}$ $\mathrm{T}$ cells into iTreg cells in the periphery is encouraged by tumor antigen in the presence of certain cytokines such as IL-2, IL10 , and TGF- $\beta$ (Levings et al., 2001b; Bergmann et al., 2007, 2008). 
Table 1 | Influence of $C D 4^{+}{ }^{C D 25}{ }^{\text {high }} T_{\text {reg }}$ cells on anti-tumor immunity.

\section{Observation}

CD4+CD25 ${ }^{\text {high }}$ Treg cells are potent inhibitors of anti-tumor immune responses and the depletion of Treg cells promotes the rejection of several transplantable murine tumor cell lines including melanoma, fibrosarcoma, leukaemia, and myeloma

\section{References}

Sakaguchi et al., 1995; Onizuka et al., 1999; Shimizu et al., 1999; Steitz et al., 2001; Jones et al., 2002

Sutmuller et al., 2001; Golgher et al., 2002

Liyanage et al., 2002; Wolf et al., 2003

$\mathrm{CD} 4+\mathrm{CD} 25^{\text {high }} \mathrm{T}$ cells from patients with epithelial malignancies are anergic to $\mathrm{T}$ cell receptor stimulation

Wolf et al., 2003

and suppress the proliferation of $\mathrm{CD} 4^{+} \mathrm{CD} 25^{-} \mathrm{T}$ cells

Using an experimental murine system and CT26 tumor cells, depletion of CD25 high Treg cells has been

Casares et al., 2003

shown to allow the host to induce both $\mathrm{CD}^{+}$and $\mathrm{CD}^{+}$anti-tumor responses following tumor challenge.

The capacity of the host to mount this anti-tumor response is lost once the number of CD25 high Treg

cells is restored over time

The depletion of CD25 $5^{\text {high }}$ Treg cells before immunization with $\mathrm{AH} 1$ (a cytotoxic T cell determinant from

Casares et al., 2003

CT26 tumor cells) permits the induction of a long-lasting anti-tumor immune response which is not

observed if immunization is conducted in the presence of CD25 high Treg cells

CD4 ${ }^{+}$CD25 high Treg cells alone can prevent effective adoptive immunotherapy

Antony et al., 2005

CD4 ${ }^{+} \mathrm{CD} 25^{\text {high }}$ Treg cells can impair $\mathrm{CD}^{+} \mathrm{T}$ cell immunity against tumor/self-antigens

Antony et al., 2005

Depletion of $\mathrm{CD} 4^{+} \mathrm{CD} 25^{\text {high }}$ Treg cells promotes a tumor-specific immune response in mice bearing

Viehl et al., 2006

pancreatic cancers

The depletion of $\mathrm{CD} 4^{+} \mathrm{CD} 25^{+}$Foxp3 ${ }^{\text {high }}$ Treg cells increases the efficacy of vaccination approaches that

Fulton et al., 2006

are aimed at increasing cellular and humoral immunity to Her-2 which is expressed on primary and

metastasized breast cancer cells

The proportion of $C D 4{ }^{+} \mathrm{CD} 25^{\text {high }} \mathrm{T}_{\text {reg }}$ cells is elevated in the peripheral blood of patients with

Cao et al., 2007

hepatocellular carcinoma (HCC), and their levels positively correlate with tumor burden

Depletion of $\mathrm{CD}_{2} 5^{+}$cells results in an accumulation of $\mathrm{CD} 4^{+}$and $\mathrm{CD} 8^{+} \mathrm{T}$ cells and $\mathrm{NK}$ cells producing

Rudge et al., 2007

IFN- $\gamma$ in mesothelioma tumor tissue

In a syngeneic murine glioma model, combining Treg cell depletion with administration of blocking

Grauer et al., 2007

CTLA-4 mAbs further boosted glioma-specific $\mathrm{CD}^{+}$and $\mathrm{CD}^{+}$effector T cells resulting in complete

tumor eradication without any signs of autoimmunity. These data illustrate that intratumoral accumulation

and activation of $\mathrm{CD}^{+}{ }^{+} \mathrm{FoxP}^{+}$Treg cells act as a dominant immune escape mechanism for gliomas

The frequency of $\mathrm{CD} 4{ }^{+} \mathrm{CD} 25^{\text {high }}$ Treg increases during disease progression and also following cancer

Strauss et al., 2007

therapy in HNSCC patients with no evident disease compared to untreated patients with active disease

$\mathrm{CD} 4{ }^{+} \mathrm{CD} 25^{\text {high }} \mathrm{T}_{\text {reg }}$ secrete IL-10 and TGF- $\beta$ and mediate immunosuppression in the tumor environment in Strauss et al., 2007

a cell contact-independent manner

Low doses of IL-2 in combination with DC vaccination are able to expand CD4+ ${ }^{+} \mathrm{D} 25^{+} \mathrm{Foxp} 3^{+}$Treg cells

in metastatic renal cell carcinoma patients suggesting that a combination of DCS-mediated

immunotherapy and Treg depletion may be a promising approach in enhancing the ability of vaccination

therapy to elicit effective anti-tumor responses in cancer patients

$\mathrm{FOXP}^{+}$Treg cells predict poor survival in patients with cyclooxygenase-2-positive uveal melanoma

Mougiakakos et al., 2010

$\mathrm{AML}$ and high-risk MDS patients have significantly larger $\mathrm{CD} 4^{+} \mathrm{CD} 25^{\text {high }} / \mathrm{CD} 4$ and

Moon et al., 2011

$\mathrm{CD} 4{ }^{+} \mathrm{CD} 25^{\text {high }}$ FoxP $3^{+} / \mathrm{CD} 4$ populations in the periphery compared to patients with autoimmune

hematologic diseases and controls, respectively

(Continued) 


\section{Observation advanced esophageal cancer patients radiochemotherapy renal cell carcinoma patients \\ INFLUENCE OF TUMORS AND TUMOR-RELATED FACTORS ON IMMUNOREGULATORY T CELL POPULATIONS}

Chemotherapy significantly decreased $\mathrm{CD} 4{ }^{+} \mathrm{CD} 25^{\text {high }}$ Treg cell numbers and FOXP3 mRNA expression in

References

Xu et al., 2011

Schuler et al., 2011

The frequency of CD4 ${ }^{+}$CD25 $5^{\text {high }}$ Treg cells is elevated in HNSCC patients and may be modulated by

Neoadjuvant sorafenib treatment significantly reduced the percentage of tumor-infiltrating Treg cells in
Desar et al., 2011
There is now a wealth of evidence indicating that factors present in the tumor microenvironment can foster immune tolerance by generating and inducing the functional capacity of $\mathrm{CD} 4{ }^{+} \mathrm{CD} 25^{\text {high }}$ Treg cell populations (Zou, 2005) and the induction of antigen-specific regulatory $\mathrm{T}$ cells from naïve cells (Zhou and Levitsky, 2007). However, the mechanism(s) underlying the recruitment, expansion and/or activation of these cells remain unclear.

The preferential accumulation of functional regulatory $\mathrm{T}$ cell populations in tumors could result from an increased recruitment, decreased emigration, and/or the local conversion of naïve $\mathrm{T}$ cells to regulatory populations by tumor-derived factors. The conversion of naïve $\mathrm{T}$ cells into inducible immunoregulatory $\mathrm{T}$ cells involves TGF- $\beta$ and other factors, and has been reviewed elsewhere (Dons et al., 2012). Should such factors be involved, then their presence might be patient/tumor and/or treatment-specific. Chemokines play a role in migratory events, as tumor cells and microenvironmental macrophages produce the chemokine CCL22, which mediates trafficking of Treg cells to the tumor (Curiel et al., 2004). More recently, it has been shown that tumor hypoxia promotes the recruitment of regulatory $\mathrm{T}$ cells to tumors via the induction of the chemokine CCL28 (Facciabene et al., 2011).

A number of tumor-related events could be influential for the induction of regulatory $\mathrm{T}$ cell populations. Regulatory $\mathrm{T}$ cells can be induced by antigenic stimulation both in vitro and in vivo [induced regulatory $\mathrm{T}$ cells (Bluestone and Abbas, 2003; Vigouroux et al., 2004)], and these can mediate tumor-specific T cell tolerance (Zhou and Levitsky, 2007). Tumors might therefore release antigens and/or other non-antigen-specific factors that activate Treg cells, thereby mediating tumor-related immunoregulation (Antony et al., 2005). It is also possible that factors expressed on, or released from tumors, might promote the development and expansion of $\mathrm{CD} 4^{+} \mathrm{CD} 25^{\text {high }}$ Treg cells.

In this regard, it is known that the prevalence of $\mathrm{CD} 4{ }^{+} \mathrm{CD} 25^{\text {high }} \mathrm{T}$ cells in tumor draining lymph nodes and the spleens of mice bearing the pancreatic adenocarcinoma Pan02, increases with tumor growth (Liyanage et al., 2006). Furthermore, tumor-related factors activate $\mathrm{CD} 4{ }^{+} \mathrm{CD} 25^{\text {high }}$ Treg cells (Li et al., 2005), expand CD $4^{+}$CD $25^{\text {high }}$ Treg cells and enhance their suppressive capacity (Cao et al., 2007). Gastric cancer cells induce human $\mathrm{CD} 4^{+}{ }^{+}$oxp $3^{+}$regulatory $\mathrm{T}$ cells via the production of TGF- $\beta$ (Yuan et al., 2011). It has also been shown that tumor-related factors activate $\mathrm{CD} 4^{+} \mathrm{CD} 25^{\text {high }}$ Treg cells (as indicated by increasing their expression of CD69) (Li et al., 2005), expand $\mathrm{CD} 4{ }^{+} \mathrm{CD} 25^{\text {high }}$ Treg cells and enhance their suppressive capacity (Cao et al., 2007).

It is also possible that the mode of tumor cell death, whether this is induced by normal cell turnover or by therapeutic intervention can influence the qualitative nature and effectiveness of the immune response induced. Cellular necrosis is an inflammatory stimulus, whereas apoptosis can have anti-inflammatory consequences, at least some of which appear to be mediated via the induction of immunoregulatory $\mathrm{T}$ cell populations (Groux et al., 1997; Steinbrink et al., 1997, 1999; Lee et al., 1998; Levings et al., 2001a; Yamagiwa et al., 2001).

\section{EFFECT OF DECREASING REGULATORY T CELLS ON ANTI-TUMOR IMMUNITY}

Modifying the numbers and function of immunoregulatory $\mathrm{T}$ cell populations could be of significant therapeutic benefit to patients with cancer (Ménétrier-Caux et al., 2012). One approach which has been considered is the use of DAB(389)IL-2 (also known as denileukin diftitox and ONTAK). This is a recombinant IL2/diphtheria toxin fusion protein which delivers diphtheria toxin to $\mathrm{CD} 25^{+}$cells and thereby abrogates the immunoregulatory influence of $\mathrm{CD} 4{ }^{+} \mathrm{CD} 25^{+}$Treg cells (Dannull et al., 2005). Following internalization, protein translation is inhibited and targeted cells undergo apoptosis (Foss, 2000). The administration of ONTAK has been shown to reduce the number of circulating Treg cells and to enhance the magnitude of vaccine-induced, tumorspecific immune responses in patients with renal cell carcinoma (Dannull et al., 2005). It also improves immunity in patients with melanoma (Chesney et al., 2006; Mahnke et al., 2007b). ONTAK has also been shown to decrease the number of circulating $\mathrm{CD} 4{ }^{+} \mathrm{CD} 25^{+}$Treg cells and the suppression mediated by these cells in patients with ovarian, lung, breast, and pancreatic cancer (Curiel, 2007b). It also improves immunity and induces tumor regression in a murine model of breast cancer (Knutson et al., 2006).

Daclizumab (Zenapex ${ }^{\circledR}$ ) and basiliximab (Simulect ${ }^{\circledR}$ ) are anti-human CD25 monoclonal antibodies (mAbs) which have been approved for use in autoimmune disease, transplantation, and cancer, including HTLV-1-induced adult $\mathrm{T}$ cell lymphoma/leukemia (reviewed in Ménétrier-Caux et al., 2012). Daclizumab treatment durably reduces circulating 
$\mathrm{CD} 25^{\text {high }} \mathrm{FOXP}^{+}$Treg cell numbers and promotes the emergence of cancer-specific cytotoxic $\mathrm{T}$ cells after vaccination with cancer antigen peptides (hTERT/survivin) in patients with metastatic breast carcinoma (Rech and Vonderheide, 2009). However, one issue which has to be considered using such approaches is the potential to influence the activated effector cells which also express CD25.

It is also possible to block the function of Treg cells via a number of cell surface receptors (reviewed in Ménétrier-Caux et al., 2012). These approaches include the use of the antiCTLA-4 antagonist mAb, two humanized forms of which are available-BMS (MDX-100: ipilimumab ${ }^{\circledR}$, Yervov $^{\circledR}$ ) and Pfizer (CP675206: tremelimumab ${ }^{\circledR}$ ). These have been evaluated in patients with melanoma, renal cell carcinoma, and prostate cancer (amongst others), with response rates of 10-15\% (reviewed in Ménétrier-Caux et al., 2012). The observation that ipilimumab ${ }^{\circledR}$ remarkably improved 1- and 2-year survival of patients with Stage IV melanoma in clinical Phase II studies resulted in approval for this indication by the US Food and Drug Administration. However, the use of CTLA-4 blocking agents has been associated with an increased risk of adverse effects including hypophysitis (Blansfield et al., 2005), diarrhea (Wolchok et al., 2010), colitis (Berman et al., 2010), thyroiditis and arthritis (Bronstein et al., 2011), and inflammatory skin rashes (Klein et al., 2009). Recent observations demonstrate the capability of anti-CTLA$4 \mathrm{mAb}$ to enhance the number of Treg cells without affecting overall immune capacity (Maker et al., 2005; Ralph et al., 2010), implies a direct activation of effector $\mathrm{T}$ cells by anti-CTLA- $4 \mathrm{mAb}$ (Ménétrier-Caux et al., 2012).

Other options include the use of Vascular Endothelial Growth Factor Receptor (VEGFR) antagonists (sutent, sorafenib) (OzaoChoy et al., 2009; Adotevi et al., 2010). Sorafenib dramatically reduces the number of peripheral and tumor-infiltrating Treg cells in patients with metastatic renal cell carcinoma (Busse et al., 2011; Desar et al., 2011) and sunitinib monotherapy decreases the number of peripheral Treg and has been shown to improve overall survival in $>70 \%$ of the patients (Adotevi et al., 2010). One can hypothesize that combining CTLA-4 blockage with immunotherapy might improve the overall effectiveness of these approaches. Indeed, ONTAK-mediated elimination of Treg cells followed by vaccination with RNA-transfected DCs significantly improves the stimulation of tumor-specific $\mathrm{T}$ cell responses in patients will renal cell carcinoma when compared with vaccination alone (Dannull et al., 2005).

The use of agonistic mAbs against OX40 (CD134), a costimulatory molecule of the TNF receptor family (Piconese et al., 2008), represents a further approach to abrogate Treg cellmediated suppression of anti-tumor immunity (Kitamura et al., 2009) and facilitate tumor rejection (Piconese et al., 2008).

Toll-like receptor (TLR2, TLR8, TLR9) agonists can also be considered as promising tools for blocking Treg cell-mediated immunosuppression. TLRs are involved in the recognition of pathogen-associated molecular patterns (PAMPs) and the activation of processes that lead to innate immune recognition. TLRs are expressed by a range of immune and non-immune cells, including Treg cells, and they play an important role in tumor immunotherapy (van Maren et al., 2008). Pre-treatment of human Treg cells with a mixture of TLR2 ligands $\left(\mathrm{Pam}_{2} \mathrm{CSK}_{4}\right.$, $\mathrm{Pam}_{3} \mathrm{CSK}_{4}$, and FSL-1) abolishes Treg cell function by downregulating the Cdk inhibitor $\mathrm{p} 27^{\mathrm{Kip} 1}$ and restoring Akt phosphorylation (Oberg et al., 2011). The synthetic bacterial lipoprotein $\mathrm{Pam}_{3} \mathrm{Cys}_{\mathrm{S}} \mathrm{SK}_{4}$, a TLR1/2 agonist which is capable of modulating T cell immune responses, has been found to induce the expansion of $\mathrm{CD}^{+}{ }^{+} \mathrm{CD} 25^{+}$Treg cells and CD $4{ }^{+} \mathrm{CD} 25^{-}$effector T cells in the absence of APCs (Liu et al., 2006a). Expanded Treg cells showed a transient loss of suppressive activity. Furthermore, $\mathrm{Pam}_{3} \mathrm{Cys}_{-} \mathrm{SK}_{4}$ renders effector cells resistant to the suppression of Treg cells by increasing IL-2 secretion. The group of Chu convincingly demonstrated that $\mathrm{Pam}_{3} \mathrm{Cys}-\mathrm{SK}_{4}$ treatment of mice with established lung carcinoma, leukemia, and melanoma, respectively, induced tumor regression and a long-lasting protective response against tumor re-challenge (Zhang et al., 2011).

$\mathrm{Pam}_{3}$ Cys-SK $\mathrm{S}_{4}$ treatment also reduces the suppressive function of Treg cells and enhances the cytotoxicity of tumor-specific cytotoxic T lymphocytes in vitro and in vivo (Zhang et al., 2011). Treg cell function can be reversed by synthetic and natural ligands for human TLR8 by a mechanism which is independent of DCs, and the adoptive transfer of TLR8 ligand-stimulated Treg cells into tumor-bearing mice enhances anti-tumor immunity (Peng et al., 2005). Furthermore, a preoperative local administration of the TLR9 agonist CpG B-type oligodeoxynucleotide (ODN) PF3512676 (formerly known as CPG 7909) lowers the frequency of $\mathrm{CD} 4{ }^{+} \mathrm{CD} 25^{\text {high }}$ Treg cells in the sentinel lymph node of 23 patients with Stage I to III melanoma (Molenkamp et al., 2007).

Another promising immunotherapy involves blockage of PD-1. Programmed death 1 (PD-1, CD279) is a key immunecheckpoint receptor expressed by several $\mathrm{T}$ cell subsets including Treg cells which plays an important role in the balance and regulation of adaptive immune responses. Programmed death ligand 1 (PD-L1) is constitutively expressed by B cells, DCs, macrophages, and $\mathrm{T}$ cells and can also be found on different tumor cells of human cancer (Jacobs et al., 2009). Activationinduced upregulation of PD-L1 occurs via TLR4 and STAT1 signaling (Loke and Allison, 2003; Freeman et al., 2006). Inhibition of PD-1 and PD-L1 interactions enhances T cell responses in vitro and mediates anti-tumor activity in pre-clinical models (Topalian et al., 2012a). Upregulation of PD-1 and its ligand might therefore be associated with immune evasion and inhibition in tumorbearing hosts. Levels of T cells expressing PD-1 are upregulated in patients with high-risk renal cell carcinoma and patients with $\mathrm{PD}$-1-positive $\mathrm{T}$ cells are at a significantly higher risk of cancer-specific death compared with patients harboring low PD1-expressing $\mathrm{T}$ cells (Thompson et al., 2007). The blockage of the PD-1/PD-L1 pathway using anti-PD-L1 mAbs abrogates Treg cell-mediated immune regulation in vitro and tolerance induction in vivo in mice (Kitazawa et al., 2007). Treg cell and PD-1 pathway signals have been studied in tumor-bearing patients. The function and phenotype of Treg cells and the expression of PD-1 and PD-L1 on different cell populations from the peripheral blood of patients with high-risk-resected stage III and IV melanoma has been studied, and PD-1 blockage found to augment the generation of melanoma antigen-specific cytotoxic $\mathrm{T}$ cells by stimulating their proliferation and, indirectly, by masking their suppression by Treg cells (Wang et al., 2009). PD-1 
blockage of Treg cells also diminished their inhibitory function (Wang et al., 2009).

In a dose-escalation study, the anti-PD-1 mAb BMS-936558 (also termed MDX-1106 and ONO-4538) has been used as singleagent in patients with advanced solid refractory tumors (Brahmer et al., 2010). This Phase I study demonstrated a favorable safety profile and preliminary evidence of clinical activity, thereby establishing the basis for a multiple-dose Phase I trial (Topalian et al., 2012b). PD-1 blockage extended the spectrum of clinical activity by immunotherapy beyond immunogenic tumor types, such as melanoma and renal-cell cancer, to treatment-refractory, metastatic non-small-cell lung cancer that is commonly not considered as being responsive to immunotherapy. This study and a companion study with anti-PD-L1 antibody (Brahmer et al., 2012) describe clinical activity with these agents validating the impact of the PD-1/PD-L1 pathway for the treatment of certain cancers. Phase II trials are under way (ClinicalTrials.gov numbers, NCT01354431 and NCT01358721), and Phase III studies with anti-PD-1 antibody for the treatment of non-small-cell lung cancer, melanoma, and renal cell cancer are being designed. Such treatment regimens offer a promising therapeutic approach for other tumor entities.

Given the difficulties that are associated with specifically targeting regulatory $\mathrm{T}$ cells, interest in the use of cyclophosphamide for inhibiting regulatory $\mathrm{T}$ cells and enhancing the induction of anti-tumor immune responses has developed (Le and Jaffee, 2012). A current perspective on the potential use of cyclophosphamide for reducing/eliminating the negative impact of regulatory $\mathrm{T}$ cells on protective anti-tumor immunity and thereby enhancing the efficacy of immunotherapeutic strategies has been provided elsewhere (Le and Jaffee, 2012). The key elements of the approach are that low-dose cyclophosphamide can enhance tumor-specific immune responses, despite the fact that it transiently decreases the frequency of regulatory $\mathrm{T}$ cell populations (Machiels et al., 2001; Motoyoshi et al., 2006; Emens et al., 2009) and that a metronomic (iterative, low-dose) approach results in a more prolonged suppression of regulatory $\mathrm{T}$ cells which returns to baseline within 4-6 weeks, even in the presence of continued administration (Cerullo et al., 2011; Le and Jaffee, 2012). It is also interesting to note that the downstream effects of cyclophosphamide treatment include the appearance of high avidity $\mathrm{T}$ effector cells (Ercolini et al., 2005; Laheru et al., 2008; Le and Jaffee, 2012).

It is important to appreciate that the influence of regulatory $\mathrm{T}$ cell populations on the induction of protective immunity might extend beyond their effects on adaptive $\mathrm{T}$ cell immunity, as $\mathrm{CD} 4^{+} \mathrm{CD} 25^{\text {high }}$ Treg cells also inhibit the cytotoxic activity of freshly isolated natural killer (NK) cells via their production of TGF- $\beta$ (Ghiringhelli et al., 2005a). CD4 ${ }^{+}$CD $25^{\text {high }}$ Treg cells from cancer patients effectively inhibit NK cell-mediated cytotoxicity (Wolf et al., 2003) and the depletion of $\mathrm{CD} 4{ }^{+} \mathrm{CD} 25^{+}$ Treg cells enhances NKT cell-mediated anti-tumor immunity in a murine mammary breast cancer model (Hong et al., 2010). It is also apparent that the relationship between Treg cells and NK cells is reciprocal, as NK-dependent increases in CCL22 secretion selectively recruits Treg cells to the tumor microenvironment (Mailloux and Young, 2009).
Given the apparent ability of the tumor microenvironment to foster immune tolerance by generating and inducing the functional capacity of regulatory $\mathrm{T}$ cell populations (Zou, 2005; Whiteside, 2012), it is essential that we better understand the influence that the tumor microenvironment and treatment modalities have on the induction and progression of the protective anti-tumor immunity which is mediated by $\mathrm{T}$ cells and NK cells.

\section{MHC CLASS I EXPRESSION, NK CELLS, AND TUMOR IMMUNITY}

Approximately 40-90\% of human tumors derived from various MHC class I positive tissues are reported to be MHC class I deficient, and MHC class I downregulation is an important mechanism of tumor escape from $\mathrm{T}$ cell-mediated immune responses (Garrido et al., 1993; Restifo, 1996; Algarra et al., 1997; Zheng et al., 1999; Johnsen et al., 2001; Groth et al., 2011). Decreased or absent MHC class I expression is frequently associated with the invasive and metastatic tumor phenotype (Garrido and Algarra, 2001; Bubenik, 2003).

Although the modulation of MHC class I expression has a significant potential impact on the application of $\mathrm{T}$ cell-based immunotherapies (Marincola et al., 2000), it does render tumor cells to be more susceptible to NK cells which target MHC class I negative (missing self) cells (Kärre et al., 1986; Ljunggren and Kärre, 1990). Proof for the receptor inhibition model of the "missing self" hypothesis comes from the work of Karlhofer and Moretta who identified MHC I-specific inhibitory receptors on the surface of NK cells such as human p58 (later termed KIR2DL; Moretta et al., 1993), mouse-specific inhibitory Ly-49 receptors (Karlhofer et al., 1992) and the multi-species heterodimeric receptor complex CD94/NKG2D (Aramburu et al., 1990; Carretero et al., 1997).

NK cells provide an essential defence against this response and their importance is illustrated by the observation that downregulation of HLA class I is associated with an improved survival of patients with non-small cell lung carcinoma (Ramnath et al., 2006), uveal melanoma (Jager et al., 2002), breast carcinoma, (Madjd et al., 2005) and colon cancer (Menon et al., 2002).

NK cells are large granular innate immune cells which account for $5-20 \%$ of human lymphocytes and can spontaneously recognize virally-infected and cancer cells (Kiessling et al., 1975; Langers et al., 2012). NK cells are characterized by the absence of the characteristic $\mathrm{T}$ cell antigens CD3 and CD4 (Stobo et al., 1973). Based on their expression of CD56 (Neuronal Cell Adhesion Molecule) and CD16 (Fcy receptor III; involved in antibody-dependent cellular cytotoxicity, ADCC) peripheral blood NK cells are grouped into two populations by the literature. The predominant population $(90 \%)$ of NK cells comprises $\mathrm{CD} 56^{\text {low }} \mathrm{CD} 16^{\text {high }}$ cells which express perforin and granzymes, and exert cytotoxic functions including ADCC. CD56 ${ }^{\text {high }} \mathrm{CD} 16^{-}$ NK cells are mainly found in lymph nodes and comprise only $5 \%$ of the NK cells in peripheral blood. Stimulated by macrophage and DC-derived type I interferons (IFNs), IL-2 or IL-15, CD56 ${ }^{\text {high }} \mathrm{CD} 16^{-} \mathrm{NK}$ cells are the primary producers of IFN $-\gamma$ and promote the activation of immune effector cells. An additional population of $\mathrm{CD} 56^{\text {high }} \mathrm{CD} 16^{+}$cells which accounts 
for $5 \%$ of peripheral blood NK cells exhibit unknown functions (Nagler et al., 1989; Beziat et al., 2011). However, they have been suggested to be an intermediate in the maturation from $\mathrm{CD} 6^{\text {high }} \mathrm{CD} 16^{-}$to $\mathrm{CD} 56^{\text {low }} \mathrm{CD} 16^{+}$(Beziat et al., 2011).

NK cells express a large profile of inhibitory and activating receptors, the latter also comprising receptors for cytokines, chemokines, and adhesion molecules (Table 2 ), and NK cell functional activity depends on the balance of the signals that are delivered (Vivier et al., 2011). The intracellular domains of activating receptors consist of immunoreceptor tyrosine-based activation motives (ITAMs) or DAP10 with its transmembranic aspartic acid residues, and these receptors include NKG2D and CD16 (Vivier et al., 2004).

NKG2D belongs to the C-type lectin like family and recognizes stress-inducible ligands such as MICA/B or ULBPs (Martinović et al., 2011) and CD16 is the main inducer of ADCC. Receptors that are characteristic of NK cells include natural cytotoxicity receptors (NCRs) such as NKp46 which exert activating functions. Inhibitory receptors are monomeric, associated with immunoreceptor tyrosine-based inhibiting motifs (ITIMs) and exert their function via the recognition of MHC class I and related molecules (Vivier et al., 2004). One inhibitory receptor which recognizes HLA-E either alone or in complex with CD94 is NKG2A (Langers et al., 2012).

Receptors of the killer-immunoglobulin (Ig) like receptor family (KIRs) possess two or three extracellular Ig-like domains and integrate incoming activating or inhibitory signals, but recognize

\section{Table 2 | NK cell receptors.}

\begin{tabular}{lllll}
\hline $\begin{array}{l}\text { Activating } \\
\text { receptors }\end{array}$ & $\begin{array}{l}\text { Inhibitory } \\
\text { receptors }\end{array}$ & $\begin{array}{l}\text { Chemotatic } \\
\text { receptors }\end{array}$ & $\begin{array}{l}\text { Cytokine } \\
\text { receptors }\end{array}$ & $\begin{array}{l}\text { Adhesion } \\
\text { receptors }\end{array}$ \\
\hline mAct.Ly49 & CEACAM-1 & CCR2 & IL-1R & CD2 \\
2B4 & CD94/NKG2A & CCR5 & IL-2R & DNAM-1 \\
CD16 & mInh.Ly49 & CCR7 & IL-12R & 31 integrins \\
CD84 & hKIR-L & CXCR1 & IL-15R & 32 integrins \\
CD94/NKG2C & KLRG-1 & CXCR3 & IL-18R & \\
CRACC & LAIR-1 & CXCR4 & IL-21R & \\
hKIR-S & hLILRB1 & CXCR6 & IFNAR & \\
Ly9 & mNKR-P1B & CX3CR1 & & \\
NKG2D & mNKR-P1D & hChem23R & & \\
mNKG2D-S & TIGIT & S1P5 & & \\
NKp46 & & & & \\
hNKp30 & & & & \\
hNKp44 & & & & \\
hNKp80 & & & & \\
mNKR-P1C & & & & \\
NTBA & & & & \\
\hline
\end{tabular}

NK cells use a wide array of activating and inhibitory receptors which recognize specific ligands expressed by target cells. MHC class I molecules expressed on self cells are engaged by NK cell inhibitory receptors such as Ly49 in mice (m/nh.Ly49) and killer immunoglobulin-like receptors (KIR) in humans (h). In contrast, expression of stress or pathogen-induced ligands, downregulation of MHC class I on target cells as well as transformation-mediated ligand expression are recognized by NK cell activating receptors (Table adapted from Vivier et al., 2011, Science 331, 44-49).
MHC class I molecules with higher affinity than ligands of activating KIRs (Martinović et al., 2011). Autoimmunity is prevented by the low expression of stress-induced ligands and the high expression of MHC class I molecules (Vivier et al., 2008; Langers et al., 2012).

\section{NK CELLS AND THE TUMOR MICROENVIRONMENT}

One way via which tumors might avoid oncolysis is by altering NK cell surface receptors. The expression of inhibitory receptors NKG2A and CD85 on NK cells is upregulated in patients with breast cancer and melanoma (Mamessier et al., 2011a,b). Furthermore, the expression of activating receptors including NKG2D, DNAM-1, Nkp30, and CD16 is downregulated in patients with invasive breast cancer and metastasis to distant sites, with the poorest prognosis being linked to the downregulation of almost all activating receptors (Mamessier et al., 2011a,b; Martinović et al., 2011).

NKG2D expression is reduced in patients with gastric cancer and this is likely to have clinical relevance given that NK cells in patients with lymph node metastases exhibit lower NKG2D expression than those patients with no metastases (Saito et al., 2012). The same study demonstrated a lower expression of NKG2D on NK cells within the primary tumor than their circulating counterparts, and also that NKG2D expression increased after surgery (Saito et al., 2012). Expression of the activation receptors NKp30, NKp46, and NKG2D, but not NKp80 and 2B4 have been reported to be reduced in patients with cervical cancer and with precursor lesions when compared to healthy controls (Garcia-Iglesias et al., 2009). In vitro studies have demonstrated that factors released by cervical cancer cell lines significantly reduce NKG2D expression on NK cells and their cytotoxic activity (Jimenez-Perez et al., 2012) and that ovarian and cervical cancer cell lines expressing CD155 can downregulate the expression of the DNAX accessary molecule 1 DNAM-1 on NK cells (Carlsten et al., 2009).

It has recently been shown that the expression of tumor necrosis factor superfamily ligands (TNFSFLs) by NK cells and apoptotic tumor activity are suppressed in patients with head and neck cancer. This suppression is tumor-dependent and possibly mediated by soluble TNF superfamily receptors (solTNFSFRs) (Baskic et al., 2012).

NK cell activity can also be modified by increasing the expression of inhibitory receptor ligands. Ovarian and cervical cancers have been reported to exhibit an upregulated expression of HLAE, a ligand for the inhibitory CD94/NKG2A complex and the upregulation of HLA-E and the infiltration of cytolytic T cell populations could be neutralized by strong overexpression of the NKG2A ligand (Gooden et al., 2011). Expression of the inhibitory receptor CD158b and the proportion of NK cells expressing it are increased in patients with non-small cellular lung cancer (Al Omar et al., 2011).

With regards to NK cell function, the tumor microenvironment and/or factors derived therefrom have been found to impair NK cell-mediated anti-tumor protection. NK cell numbers can be reduced, as has been found in patients with non-small cellular lung cancer (NSCLC) and melanoma (Al Omar et al., 2011; Martinović et al., 2011), and this might impact on the 
overall potential of patients to elicit NK cell mediated immunity. Degranulation and NK cell-mediated killing, as well as IFN- $\gamma$ and TNF- $\alpha$ secretion and induction of ADCC is impaired in patients with metastatic breast cancer via a mechanism which appears to involve TGF $\beta$-1 and prostaglandin $\mathrm{E}_{2}\left(\mathrm{PGE}_{2}\right)$ (Holt et al., 2011; Mamessier et al., 2011a,b). These findings have been confirmed by studies that have related an NK cell functional profile with clinical stages in melanoma and demonstrated that CD107a (a marker for degranulation), IFN- $\gamma$ and TNF- $\alpha$ levels as well as NKG2D were downregulated, whereas CD158b, an inhibitory receptor was upregulated (Martinović et al., 2011). An interesting finding has been that NK activity in the peripheral blood of patients with breast cancer is lower than that in controls and also that the activity of NK cells in patients with HER2- cancers is significantly lower than that in patients with HER2+ tumors (Dewan et al., 2009). NK cell activity has also been shown to be reduced in patients with cervical cancer (Garcia-Iglesias et al., 2009).

Tumors and macrophages produce $\mathrm{H}_{2} \mathrm{O}_{2}$ which can be detected by flow cytometry using intracellular formation of $2^{\prime}, 7^{\prime}$-dichlorodihydrofluorescein as a measure of reactive oxygen species. There is a negative correlation between $\mathrm{CD} 56^{\mathrm{dim}}$ cell numbers and $\mathrm{H}_{2} \mathrm{O}_{2}$ concentration in gastric and oesophageal cancer (Izawa et al., 2011). This population is more susceptible to apoptosis than CD56 $6^{\text {bright }}$, and an observed impairment of ADCC could be reversed by catalase (Izawa et al., 2011). PGE 2 secretion depends on the rate limiting enzyme cyclooxygenase-2 (COX-2) which is overexpressed in some cancers. $\mathrm{PGE}_{2}$ also has a negative influence on NK cell function via the receptors CD16, NCRs, and NKG2D (Holt et al., 2011).

However, it remains unclear whether the impaired functionality of patient-derived NK cells is permissive of the development of cancer or whether the observed altered phenotype and function result from its presence.

\section{EFFECT OF RADIOTHERAPY ON A TUMOR'S CAPACITY TO INFLUENCE PROTECTIVE INNATE AND ADAPTIVE IMMUNITY}

The direct effect of irradiation on immune cells and its influence of protective anti-tumor immunity has been considered elsewhere in this Research Topic (Manda et al., 2012; Multhoff and Radons, 2012; Rödel et al., 2012; Rubner et al., 2012; Schmid and Multhoff, 2012). However, there is much less information relating to the influence of radiotherapy on the tumor's capacity to modify antitumor immunity, particularly with regards to direct effects of tumor-derived factors on infiltrating $\mathrm{NK}$ and immunoregulatory $T$ cell populations. In contrast to the immunosuppressive effects of whole body irradiation, focal radiation such as that used for treatment of many types of solid tumors has the capacity to influence the tumor microenvironment in a way which can enhance the infiltration and the activation of immune cell types which might foster and/or suppress tumor development (de Visser et al., 2006; Shiao and Coussens, 2010).

Radiotherapy induces the expression of nuclear factor (NF)-кB and this has a number of downstream effects with regards to the expression of molecules that promote a pro-inflammatory environment. Radiotherapy stimulates the migration and function of leukocytes via the release of cytokines such as TNF- $\alpha$
(Shakhov et al., 1990), IL-1 (Mori and Prager, 1996), chemokines (Wickremasinghe et al., 2004), the expression of adhesion molecules such as ICAM-1 and E-selectin on vascular endothelial cells within the tumor microenvironment (Iademarco et al., 1992; Caldenhoven et al., 1994; Schindler and Baichwal, 1994; Hallahan et al., 1996; Handschel et al., 1999). In vivo experiments using a murine model of mammary carcinoma have demonstrated that radiotherapy-induced expression of the chemokine CXCL16 is an important mechanism which mediates the infiltration of $\mathrm{CD} 8^{+} \mathrm{T}$ effector cells following treatment, as the recruitment of $\mathrm{CD} 8^{+} \mathrm{T}$ cells and responsiveness to treatment are reduced in mice that are deficient for its ligand (CXCR6) (Matsumura et al., 2008).

In vitro experiments using a range of different tumor cell types also suggest that the induction of CXCL16 is a common response to radiotherapy (Matsumura and Demaria, 2010). This could have far-reaching effects with regards to the efficacy of radiotherapy and the immunological mechanisms that are involved. Stromal cell-derived factor (SDF)- $1 \alpha$ also appears to an important factor for to the immunological consequences of radiotherapy, as inhibiting its pathway prevents macrophage infiltration and delays tumor regrowth (Kozin et al., 2010).

Ionizing radiation also impacts signaling via pattern recognition receptors (PRRs). These receptors interact with exogenous PAMPs such as endotoxin and endogenous "alarmins" such as high-mobility-group-box 1 (HMGB1), hyaluronan, and heat shock (stress) proteins which together comprise the group of danger-associated molecular patterns (DAMPs) (Bianchi, 2007; Kawai and Akira, 2011). The export of DAMPs is achieved by several mechanisms such as (1) leakage from necrotic cells, (2) increased synthesis and post-translational modification in response to inflammation, and (3) degradation of inactive precursors into TLR-mimetic cleavage products in inflammatory environments (Mencin et al., 2009).

The impact of PRR signaling on radiation responses has been documented by Shan and colleagues who demonstrated that radiation-induced release of IL-12 and IL-18 from macrophages is accompanied by NF- $\kappa \mathrm{B}$ activation and an upregulation of CD14 and TLR4/MD2 expression, thereby implying the involvement of the Toll signaling pathway (Shan et al., 2007). On B cells and DCs, TLR-related radioprotective $105 \mathrm{kDa}$ (RP105) was identified as being similar to TLR4 because of its ability to interact with the MD2-like adaptor MD1 (Miyake et al., 1995; Fugier-Vivier et al., 1997). RP105/MD1 directly interacts with TLR4/MD2, thus abolishing the LPS binding capacity of the complex (Divanovic et al., 2005). Together with its ability to regulate TLR4 signaling in vitro and LPS responses in vivo, RP105 can be considered as being a negative regulator of TLR4 responses.

From these observations it can be assumed that proinflammatory responses to radiation and TLR signaling not only increase the impact of tumor-promoting factors in the tumor and the microenvironment, but also might function as crucial targets in radiotherapy. It is interesting to note that the radiation-induced release of HMGB1 by dying tumor cells enables the manifestation of tumor antigen-specific $\mathrm{T}$ cell immunity (Apetoh et al., 2007). This pathway depends on the interaction of HMGB1 with TLR4 expressed on DCs. During chemotherapy or radiotherapy, DCs require signaling through TLR4 for efficient processing and 
cross-presentation of antigen from dying tumor cells. Moreover, patients with breast cancer who carry a TLR4 "loss-of-function" allele relapse more quickly after radiotherapy and chemotherapy than those carrying the normal TLR4 allele.

These results delineate a clinically-relevant immunoadjuvant pathway which is triggered by tumor cell death. Silencing of HMGB1 expression by an HMGB1-specific RNAi lentiviral vector has been shown to reduce matrix metalloproteinase 9 (MMP9) expression and metastatic capacity in MGC-803 gastric carcinoma cells (Song et al., 2011). HMGB1-specific silencing also significantly decreased cell proliferation and sensitized cells to oxaliplatin-induced apoptosis mediated via the caspase-3 pathway (Song et al., 2011), rendering HMGB1 a promising target structure in cancer therapy.

An intriguing novel observation has reported by Kono and colleagues who demonstrated that $38 \%$ of patients with oesophageal squamous cell carcinoma harbored elevated HMGB1 serum levels after chemoradiotherapy and showed concomitant tumor antigen-specific $\mathrm{T}$ cell responses (Suzuki et al., 2012). The same study revealed an upregulated HMGB1 expression within the tumor microenvironment in patients with ESCC after preoperative chemoradiotherapy, but not in those without chemoradiotherapy, and the degree of HMGB1 positively correlated with patient survival (Suzuki et al., 2012). Both, irradiation and chemotherapy induces upregulation of HMGB1 and the chaperone protein calreticulin. Furthermore, HMGB1 is able to induce maturation of DCs, implying that chemoradiation induces tumor antigen-specific $\mathrm{T}$ cell responses, and that chemoradiation-mediated HMGB1 production is related to clinical outcome (Suzuki et al., 2012).

Using an in vitro approach, in which the transmigration of $\mathrm{T}$ cell populations toward supernatants derived from primary cultures of tumor cells derived from patients with head and neck carcinomas, Schmidtner et al. (2009) have demonstrated that supernatants from irradiated cells significantly decrease the transmigration of $\mathrm{CD} 4{ }^{+} \mathrm{CD} 25^{\text {high }}$ Foxp $3^{+}$Treg cells, yet had no effect on the transmigration of $\mathrm{CD} 4{ }^{+} \mathrm{CD} 25^{-} \mathrm{T}$ cells. The observed effects on cell migratory properties have been attributed to treatment-associated increases chemokine (C-C motif) ligand 22 (CCL22) levels in the tumor cell supernatants (Schmidtner et al., 2009). These findings contrast with the effects that are seen following hyperthermia treatment which appears to promote the migration of $\mathrm{CD} 4{ }^{+} \mathrm{CD} 25^{\text {high }}$ Foxp $3^{+}$Treg cells (Schmidtner et al., 2009). These potentially important findings indicate that radiotherapy may play some role in reducing the capacity of tumors to promote the prevalence of $\mathrm{CD} 4{ }^{+} \mathrm{CD} 25^{\text {high }}$ Foxp $3^{+}$Treg cells in the tumor microenvironment and might, as a consequence, facilitate the induction or protective innate and adaptive tumor immunity.

In an attempt to increase the therapeutic benefit of irradiation, several studies have combined molecular oncology therapeutics with radiation. Radiation sensitization, in which cytotoxic enhancers co-operate with radiation within the radiation field, aims to produce a greater (synergistic) anti-tumor effect than would be expected from simple additive cell killing (Zaidi et al., 2009). Oncolytic viruses represent prime candidates for enhancing the immunogenicity of the tumor microenvironment. Oncolytic virotherapy may be immunomodulatory via tumor cell death, production of endogenous danger signals, the release of tumor-derived cytokines and direct effects upon cells of the innate immune system (Prestwich et al., 2008).

Pre-clinical models suggest that tumor viral therapy mediates an early influx of immune cells, such as macrophages and NK cells (Benencia et al., 2005; Diaz et al., 2007). These changes within the tumor hold the potential to alter the pre-existing immunosuppressive microenvironment, in favor of the generation of therapeutic immune responses. DCs are critical for the subsequent generation of antigen-specific or adaptive immune responses. According to Prestwich et al. (2008), the outcome of the innate response is finely balanced between promotion of tumor clearance and viral clearance that limits the efficacy. Strategies that involve combining oncolytic virotherapy with external beam radiotherapy may help to exploit synergies between the two treatment modalities (Hingorani et al., 2007; Harrington et al., 2008).

Melcher and colleagues have demonstrated a synergy between oncolytic reovirus RT3D, a naturally occurring nonpathogenic, double-stranded RNA virus isolated from the respiratory and gastrointestinal tracts of humans and external beam radiotherapy in tumor cell lines in vitro and in three different in vivo tumor models (Twigger et al., 2008). The same group has now completed a Phase I dose-escalation study of this combination strategy in patients receiving two different dose schedules of palliative radiotherapy and confirmed the safety and tolerability of this approach (Harrington et al., 2010). The study further showed that virus is not shed after administration, thereby opening the way for outpatient treatment regimens. Most importantly, the ease of virus administration and the fact that there was no exacerbation of radiation-induced toxicity strongly support development of this combinatory treatment in patients with newly diagnosed, radiocurable cancers.

Several potentially positive theoretical interactions exist between RT3D and radiotherapy. Tumor radiation resistance is, at least partly, mediated by the Ras signaling pathway (McKenna et al., 2003). Moreover, activating Ras mutations, EGFR overexpression, and phosphorylation of Akt and phosphoinositide-3kinase have been found as being associated with radioresistance in vitro and, with respect to EGFR and Akt, to the failure of radiotherapy in cancer patients (Gupta et al., 2002, 2003; McKenna et al., 2003). Blockage of the Ras signaling pathway sensitizes cells to radiation-induced cytotoxicity (Bernhard et al., 1996; Russell et al., 1999).

Radiotherapy in combination with oncolytic reovirus also represents a promising immunotherapeutic approach, as radiotherapy enhances $\mathrm{T}$ cell trafficking (Lugade et al., 2005), antigen presentation, and $\mathrm{T}$ cell recognition of tumor cells (Reits et al., 2006). Radiotherapy is also locally immunosuppressive by killing lymphocytes, and the optimal combination to enhance antitumor immune responses will require careful consideration of dose fractionation and treatment scheduling.

Another potentially important element of the tumor microenvironment which might be altered following the induction of cell death following radiotherapy relates to the release of heat 
shock proteins. Although typically regarded as being intracellular proteins, stress proteins, including members of the 60 and $70 \mathrm{kDa}$ families (Hsp60, Hsp70) can be released from a variety of cell types and have been identified in the peripheral circulation in a number of healthy and diseased states (Pockley et al., 1998, 1999, 2000; Rea et al., 2001; Pockley, 2003; Henderson and Pockley, 2010; Henderson et al., 2010). In addition to acting as potent inducers of inflammatory immunity, these proteins can also ameliorate inflammatory events/conditions by inducing/activating regulatory $\mathrm{T}$ cell populations (Borges et al., 2012) or by reducing $\mathrm{T}$ cell responses and the stimulatory capacity of monocyte-derived DCs (Stocki et al., 2012).

Hsp70 can be released from human glioma, prostate cancer cell lines, the human erythroleukemic cell line K562, and the 4T1 breast carcinoma cell line (Guzhova et al., 2001; Wang et al., 2004; Bausero et al., 2005; Evdonin et al., 2006; Mambula and Calderwood, 2006a,b). Although the relationship between intracellular Hsp70 expression and release has yet to be clarified, increasing the expression of $\mathrm{Hsp} 70$ by transfecting prostate cancer cells with cDNA encoding for human Hsp70 enhances their release of Hsp70 (Wang et al., 2004), as does heat treatment (Mambula and Calderwood, 2006a). Non-lethal heat, IFN- $\gamma$, and IL-10 also increase Hsp70 release from K562 and 4T1 cells (Bausero et al., 2005). Although in a small cohort of patients, it has been reported that radiotherapy increases circulating Hsp70 levels in patients with prostate cancer and it might be that this reflects increases in Hsp70 levels within the tumor microenvironment (Hurwitz et al., 2010).

Although one study reports that Hsp70 release from prostate cancer cells protects against tumor growth (Wang et al., 2004), presumably via its capacity to induce tumor-specific immunity (Calderwood et al., 2005, 2006), Hsp70 might also adversely influence anti-tumor immunity by activating $\mathrm{CD} 4{ }^{+} \mathrm{CD} 25^{\text {high }}$ Treg cells via its capacity to interact with TLRs expressed thereon. Released Hsp70 might also have direct effects on tumor cell survival following radiotherapy, as radiation-induced tumor cell killing has been shown to be significantly enhanced by the addition of Hsp70 protein via a mechanism which appears to involve necrosis rather than apoptosis (Schilling et al., 2009).

In addition to the secretion of Hsp70 from viable tumor cells and its inevitable release from necrotic cells within the tumor mass, a form of Hsp70 is frequently expressed on the membranes of a number of cancers, and metastases derived therefrom, but not on their non-malignant counterparts (Multhoff et al., 1995, 1997; Botzler et al., 1996, 1998; Multhoff and Hightower, 1996; Multhoff et al., 2001; Gehrmann et al., 2002; Shin et al., 2003; Multhoff, 2007, 2009). It is also the case that the expression of this membrane form of Hsp70 is enhanced by clinically applied interventions such as radio- and chemotherapy (Gehrmann et al., 2008a,b, 2010) (Figure 1).

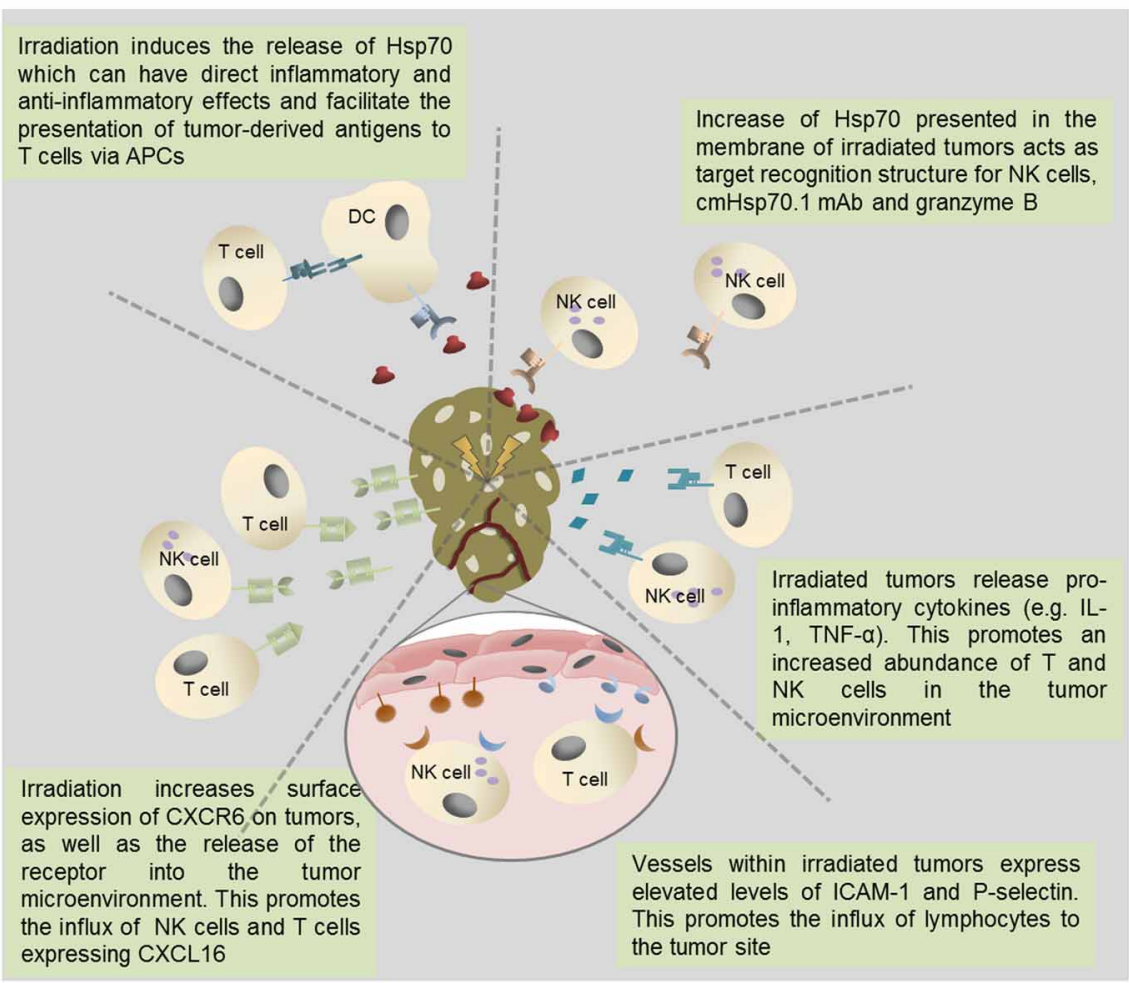

Dendritic cell (DC) DC

T cell

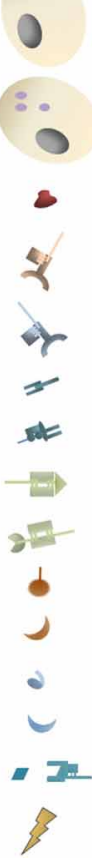

NK cell

Hsp70

NK receptor for Hsp70 (e.g. CD94)

APC receptor for $\mathrm{Hsp} 70$

MHC class 1

T cell receptor

CXCR6

CXCL16

ICAM-1

Integrins

P-selectin

P-selectin glycoprotein ligand-1

Pro-inflammatory cytokines \& ligands

Irradiation source

FIGURE 1 | Potential immunological benefits of tumor irradiation. Increased recruitment of immunoregulatory $T$ cell populations could negatively impact on protective anti-tumor immunity. 
Membrane Hsp70 acts as a tumor-specific recognition structure for $\mathrm{CD} 4^{+} \mathrm{NK}$ cells and, in the presence of Hsp70 and cytokine (IL-2/IL-15) co-activation, it enhances the capacity of NK cells these cells to kill membrane Hsp70 positive tumor cells (Botzler et al., 1996, 1998; Gross et al., 2003a,b). Membrane Hsp70 expressing tumors can also be imaged and targeted using a specific monoclonal antibody (cmHsp70.1) or a glycosylated recombinant human granzyme B (Stangl et al., 2010, 2011; Gehrmann et al., 2011, 2012). It might therefore be that the release of heat shock proteins such as Hsp70 into the tumor microenvironment by radiation-induced cell death has a number of immunoregulatory effects that influence many aspects of protective anti-tumor immunity (Figure 1).

\section{CONCLUDING STATEMENT}

Although it is known that tumors can have a range of immunoregulatory effects that can have tumor-suppressive and tumor-stimulatory properties, an improved insight into the mechanisms and factors involved is required in order to design strategies for promoting the efficacy of therapeutic interventions such as radiotherapy. Focal radiotherapy can elicit antitumor immunity by the following mechanisms: (1) boosting trafficking of APCs to the tumor site, (2) augmenting antigen uptake of irradiated tumor cells; (3) increasing the maturation of APCs, (4) inducing maturation of immune effector cells in order to generate a robust immune response, and (5) limiting the immunomodulatory capacity of Treg cell populations.

\section{REFERENCES}

Adotevi, O., Pere, H., Ravel, P., Haicheur, N., Badoual, C., Merillon, N., et al. (2010). A decrease of regulatory $\mathrm{T}$ cells correlates with overall survival after sunitinibbased antiangiogenic therapy in metastatic renal cancer patients. J. Immunother. 33, 991-998.

Algarra, I., Collado, A., and Garrido, F. (1997). Altered MHC class I antigens in tumors. Int. J. Clin. Lab. Res. 27, 95-102.

Al Omar, S. Y., Marshall, E., Middleton, D., and Christmas, S. E. (2011). Increased killer immunoglobulinlike receptor expression and functional defects in natural killer cells in lung cancer. Immunology 133, 94-104.

Antony, P. A., Piccirillo, C. A., Akpinarli, A., Finkelstein, S. E., Speiss, P. J., Surman, D. R., et al. (2005). $\mathrm{CD}^{+} \mathrm{T}$ cell immunity against a tumor/self-antigen is augmented by $\mathrm{CD} 4^{+} \mathrm{T}$ helper cells and hindered by naturally occurring T regulatory cells. J. Immunol. 174, 2591-2601.

Apetoh, L., Ghiringhelli, F., Tesniere, A., Obeid, M., Ortiz, C., Criollo, A., et al. (2007). Toll-like receptor 4-dependent contribution of the

Accumulation of Treg cells in cancer patients is a major factor in tumor immune escape. Targeting of these cells might thus provide a mechanism by which anti-tumor immune responses could be restored. Immunotherapeutic strategies which target Treg cells and deplete functional Treg cells from the tumor microenvironment cells appear to shift the immune balance in support of effective anti-cancer immune responses. It is likely that effective anti-cancer strategies will depend on multimodal approaches which combine immunotherapy with targeted therapies that stimulate protective immune effector activity and downregulate the suppressive effects of Treg cells.

\section{ACKNOWLEDGMENTS}

Graham Pockley's laboratory is supported by Core Funding received from the John and Lucille van Geest Foundation, the Breast Cancer Campaign (2008MayPR27; 2009MaySP13) and a Wellcome Trust Equipment Grant (084399). Gabriele Multhoff's laboratory is supported, in part, by the Helmholtz Zentrum München (Clinical Cooperation Group- "Innate Immunity in Tumor Biology"), the Deutsche Forschungsgemeinschaft (SFB824/1; DFG Cluster of Excellence, Munich Advanced Photonics, MAP), the Bundesministerium für Forschung und Technologie (BMBF BioChance plus, 0313686A; BMBF MOBITUM, 01EZ0826; BMBF KompetenzverbundStrahlenforschung, 03NUK007E; BMBF Innovative Therapies, 01GU0823; BMBF m4 Spitzencluster, 01EX1021C), EU (CARDIORISK FP7-211403) and by multimmune $\mathrm{GmbH}$, Munich.

release of heat shock protein 72 . J. Immunol. 175, 2900-2912.

Benencia, F., Courreges, M. C., ConejoGarcia, J. R., Mohamed-Hadley, A., Zhang, L., Buckanovich, R. J., et al. (2005). HSV oncolytic therapy upregulates interferon-inducible chemokines and recruits immune effector cells in ovarian cancer. Mol. Ther. 12, 789-802.

Bergmann, C., Strauss, L., Wang, Y., Szczepanski, M. J., Lang, S., Johnson, J. T., et al. (2008). T regulatory type 1 cells in squamous cell carcinoma of the head and neck: mechanisms of suppression and expansion in advanced disease. Clin. Cancer Res. 14, 3706-3715.

Bergmann, C., Strauss, L., Zeidler, R., Lang, S., and Whiteside, T. L. (2007). Expansion of human $\mathrm{T}$ regulatory type 1 cells in the microenvironment of cyclooxygenase 2 overexpressing head and neck squamous cell carcinoma. Cancer Res. 67, 8865-8873.

Berman, D., Parker, S. M., Siegel, J., Chasalow, S. D., Weber, J., Galbraith, S., et al. (2010). Blockade of cytotoxic T-lymphocyte antigen- 4 by ipilimumab results in dysregulation of gastrointestinal immunity in patients with advanced melanoma. Cancer Immun. 10, 11.

Bernhard, E. J., Kao, G., Cox, A. D., Sebti, S. M., Hamilton, A. D., Muschel, R. J., et al. (1996). The farnesyltransferase inhibitor FTI-277 radiosensitizes H-ras-transformed rat embryo fibroblasts. Cancer Res. 56, 1727-1730.

Berntsen, A., Brimnes, M. K., thor Straten, P., and Svane, I. M (2010). Increase of circulating $\mathrm{CD}^{+}{ }^{+} \mathrm{CD} 25^{\text {high }} \mathrm{Foxp}^{+}$regulatory $\mathrm{T}$ cells in patients with metastatic renal cell carcinoma during treatment with dendritic cell vaccination and low-dose interleukin-2. J. Immunother. 33, 425-434.

Beziat, V., Duffy, D., Quoc, S. N., Le Garff-Tavernier, M., Decocq, J., Combadiere, B., et al. (2011). CD56 ${ }^{\text {bright }} \mathrm{CD} 16^{+}$NK cells: a functional intermediate stage of $\mathrm{NK}$ cell differentiation. J. Immunol. 186, 6753-6761.

Bianchi, M. E. (2007). DAMPs, PAMPs and alarmins: all we need to know about danger. J. Leukoc. Biol. 81, $1-5$.

Bilate, A. M., and Lafaille, J. J. (2012). Induced CD ${ }^{+}$Foxp $^{+}$ regulatory $\mathrm{T}$ cells in immune 
tolerance. Annu. Rev. Immunol. 30, 733-758.

Biollaz, G., Bernasconi, L., Cretton, C., Puntener, U., Frei, K., Fontana, A., et al. (2009). Site-specific antitumor immunity: differences in DC function, TGF-beta production and numbers of intratumoral Foxp $3^{+}$Treg. Eur. J. Immunol. 39, 1323-1333.

Blansfield, J. A., Beck, K. E., Tran, K., Yang, J. C., Hughes, M. S., Kammula, U. S., et al. (2005). Cytotoxic T-lymphocyte-associated antigen-4 blockage can induce autoimmune hypophysitis in patients with metastatic melanoma and renal cancer. J. Immunother. 28, 593-598.

Bluestone, J. A., and Abbas, A. K. (2003). Natural versus adaptive regulatory T cells. Nat. Rev. Immunol. 3, 253-257.

Borges, T. J., Wieten, L., van Herwijnen, M. J., Broere, F., van der Zee, R., Bonorino, C., et al. (2012). The anti-inflammatory mechanisms of Hsp70. Front. Immun. 3:95. doi: 10.3389/fimmu.2012.00095

Botzler, C., Issels, R., and Multhoff, G. (1996). Heat-shock protein 72 cell-surface expression on human lung carcinoma cells in association with an increased sensitivity to lysis mediated by adherent natural killer cells. Cancer Immunol. Immunother. 43, 226-230.

Botzler, C., Li, G., Issels, R. D., and Multhoff, G. (1998). Definition of extracellular localized epitopes of Hsp70 involved in an NK immune response. Cell Stress Chaperones 3, 6-11.

Brahmer, J. R., Drake, C. G., Wollner, I., Powderly, J. D., Picus, J., Sharfman, W. H., et al. (2010). Phase I study of single-agent anti-programmed death-1 (MDX-1106) in refractory solid tumors: safety, clinical activity, pharmacodynamics, and immunologic correlates. J. Clin. Oncol. 28, 3167-3175.

Brahmer, J. R., Tykodi, S. S., Chow, L. Q., Hwu, W. J., Topalian, S. L., Hwu, P., et al. (2012). Safety and activity of anti-PD-L1 antibody in patients with advanced cancer. N. Engl. J. Med. 366, 2455-2465.

Bronstein, Y., Ng, C. S., Hwu, P., and Hwu, W. J. (2011). Radiologic manifestations of immune-related adverse events in patients with metastatic melanoma undergoing anti-CTLA-4 antibody therapy. AJR Am. J. Roentgenol. 197, W992-W1000.

Bruder, D., Probst-Kepper, M., Westendorf, A. M., Geffers, R., Beissert, S., Loser, K., et al. (2004).
Neuropilin-1: a surface marker of regulatory T cells. Eur. J. Immunol. 34, 623-630.

Bubenik, J. (2003). Tumour MHC class I downregulation and immunotherapy. Oncol. Rep. 10, 2005-2008.

Busse, A., Asemissen, A. M. Nonnenmacher, A., Braun, F., Ochsenreither, S., Stather, D., et al. (2011). Immunomodulatory effects of sorafenib on peripheral immune effector cells in metastatic renal cell carcinoma. Eur. J. Cancer 47, 690-696.

Caldenhoven, E., Coffer, P., Yuan, J., Van de Stolpe, A., Horn, F., Kruijer, W., et al. (1994). Stimulation of the human intercellular adhesion molecule-1 promoter by interleukin-6 and interferongamma involves binding of distinct factors to a palindromic response element. J. Biol. Chem. 269, 21146-21154.

Calderwood, S. K., Khaleque, M. A., Sawyer, D. B., and Ciocca, D. R. (2006). Heat shock proteins in cancer: chaperones of tumorigenesis. Trends Biochem. Sci. 31, 164-172.

Calderwood, S. K., Thériault, J. R., and Gong, J. (2005). Message in a bottle: role of the $70-\mathrm{kDa}$ heat shock protein family in anti-tumor immunity. Eur. J. Immunol. 35, 2518-2527.

Cao, M., Cabrera, R., Xu, Y., Firpi, R., Zhu, H., Liu, C., et al. (2007). Hepatocellular carcinoma cell supernatants increase expansion and function of $\mathrm{CD} 4{ }^{+} \mathrm{CD} 25^{+}$ regulatory $\mathrm{T}$ cells. Lab. Invest. 87, 582-590.

Carlsten, M., Norell, H., Bryceson, Y. T., Poschke, I., Schedvins, K., Ljunggren, H. G., et al. (2009). Primary human tumor cells expressing CD155 impair tumor targeting by down-regulating DNAM-1 on NK cells. J. Immunol. 183, 4921-4930.

Carretero, M., Cantoni, C., Bellon, T., Bottino, C., Biassoni, R., Rodriguez, A., et al. (1997). The CD94 and NKG2-A C-type lectins covalently assemble to form a natural killer cell inhibitory receptor for HLA class I molecules. Eur. J. Immunol. 27, 563-567.

Casares, N., Arribillaga, L., Sarobe, P., Dotor, J., Lopez-Diaz de Cerio, A., Melero, I., et al. (2003). $\mathrm{CD} 4{ }^{+} \mathrm{CD} 25^{+}$regulatory cells inhibit activation of tumor-primed $\mathrm{CD}^{+}{ }^{+} \mathrm{T}$ cells with IFN- $\gamma$ dependent antiangiogenic activity, as well as long-lasting tumor immunity elicited by peptide vaccination. J. Immunol. 171, 5931-5939.

Cerullo, V., Diaconu, I., Kangasniemi, L., Rajecki, M., Escutenaire,
S., Koski, A., et al. (2011) Immunological effects of lowdose cyclophosphamide in cancer patients treated with oncolytic adenovirus. Mol. Ther. 19, 1737-1746.

Chesney, J., Rasku, M., Clem, A. and Miller, D. (2006). Denileukin diftitox depletes $\mathrm{T}$ regulatory cells and causes regression of melanoma metastases in humans (abstract). Eur. J. Cancer Suppl. 4, 84.

Conroy, H., Galvin, K. C., Higgins, S. C., and Mills, K. H. (2012). Gene silencing of TGF-betal enhances antitumor immunity induced with a dendritic cell vaccine by reducing tumor-associated regulatory $\mathrm{T}$ cells. Cancer Immunol. Immunother. 61 , 425-431.

Curiel, T. J. (2007a). Regulatory T-cell development: is Foxp3 the decider? Nat. Med. 13, 250-253.

Curiel, T. J. (2007b). Tregs and rethinking cancer immunotherapy. J. Clin. Invest. 117, 1167-1174.

Curiel, T. J., Coukos, G., Zou, L., Alvarez, X., Cheng, P., Mottram, P. et al. (2004). Specific recruitment of regulatory $\mathrm{T}$ cells in ovarian carcinoma fosters immune privilege and predicts reduced survival. Nat. Med. 10, 942-949.

Dannull, J., Su, Z., Rizzieri, D., Yang, B. K., Coleman, D., Yancey, D., et al. (2005). Enhancement of vaccinemediated antitumor immunity in cancer patients after depletion of regulatory $\mathrm{T}$ cells. J. Clin. Invest $115,3623-3633$

Desar, I. M., Jacobs, J. H., HulsbergenvandeKaa, C. A., Oyen, W. J., Mulders, P. F., van der Graaf, W. T., et al. (2011). Sorafenib reduces the percentage of tumour infiltrating regulatory $\mathrm{T}$ cells in renal cell carcinoma patients. Int. J. Cancer 129, 507-512.

de Visser, K. E., Eichten, A., and Coussens, L. M. (2006). Paradoxical roles of the immune system during cancer development. Nat. Rev. Cancer 6, 24-37.

Dewan, M. Z., Takada, M., Terunuma, H., Deng, X., Ahmed, S., Yamamoto, N., et al. (2009). Natural killer activity of peripheral-blood mononuclear cells in breast cancer patients. Biomed. Pharmacother. 63, 703-706.

Diaz, R. M., Galivo, F., Kottke, T., Wongthida, P., Qiao, J., Thompson, J., et al. (2007). Oncolytic immunovirotherapy for melanoma using vesicular stomatitis virus. Cancer Res. 67, 2840-2848.

Divanovic, S., Trompette, A., Atabani, S. F., Madan, R., Golenbock, D. T., Visintin, A., et al. (2005). Negative regulation of Toll-like receptor 4 signaling by the Toll-like receptor homolog RP105. Nat. Immunol. 6, 571-578.

Dons, E. M., Raimondi, G., Cooper, D. K., and Thomson, A. W. (2012) Induced regulatory $\mathrm{T}$ cells: mechanisms of conversion and suppressive potential. Hum. Immunol. 73, 328-334.

Emens, L. A., Asquith, J. M., Leatherman, J. M., Kobrin, B. J., Petrik, S., Laiko, M., et al. (2009). Timed sequential treatment with cyclophosphamide, doxorubicin, and an allogeneic granulocytemacrophage colony-stimulating factor-secreting breast tumor vaccine: a chemotherapy doseranging factorial study of safety and immune activation. J. Clin. Oncol. 27, 5911-5918.

Ercolini, A. M., Ladle, B. H., Manning, E. A., Pfannenstiel, L. W., Armstrong, T. D., Machiels, J. P., et al. (2005). Recruitment of latent pools of high-avidity CD ${ }^{+} \mathrm{T}$ cells to the antitumor immune response. J. Exp. Med. 201, 1591-1602.

Erdman, S. E., Rao, V. P., Poutahidis, T., Ihrig, M. M., Ge, Z., Feng, Y., et al. (2003). CD4 ${ }^{+} \mathrm{CD} 25^{+}$regulatory lymphocytes require interleukin 10 to interrupt colon carcinogenesis in mice. Cancer Res. 63, 6042-6050.

Evdonin, A. L., Martynova, M. G., Bystrova, O. A., Guzhova, I. V., Margulis, B. A., and Medvedeva, N. D. (2006). The release of Hsp70 from A431 carcinoma cells is mediated by secretory-like granules. Eur. J. Cell Biol. 85, 443-455.

Facciabene, A., Motz, G. T., and Coukos, G. (2012). T-regulatory cells: key players in tumor immune escape and angiogenesis. Cancer Res. 72, 2162-2171.

Facciabene, A., Peng, X., Hagemann, I. S., Balint, K., Barchetti, A., Wang, L. P., et al. (2011). Tumour hypoxia promotes tolerance and angiogenesis via CCL28 and T(reg) cells. Nature 475, 226-230.

Foss, F. M. (2000). DAB(389)IL-2 (ONTAK): a novel fusion toxin therapy for lymphoma. Clin. Lymphoma 1, 110-116.

Freeman, G. J., Wherry, E. J., Ahmed, R., and Sharpe, A. H. (2006). Reinvigorating exhausted HIV specific $T$ cells via PD-1-PD-1 ligand blockade. J. Exp. Med. 203, 2223-2227.

Fugier-Vivier, I., de Bouteiller, O., Guret, C., Fossiez, F., Banchereau, J., Mattei, M. G., et al. (1997). Molecular cloning of human RP105. Eur. J. Immunol. 27, 1824-1827. 
Fulton, A., Miller, F., Weise, A., and Wei, W. Z. (2006). Prospects of controlling breast cancer metastasis by immune intervention. Breast Dis. 26, 115-127.

Garcia-Iglesias, T., Del Toro-Arreola, A., Albarran-Somoza, B., Del ToroArreola, S., Sanchez-Hernandez, P. E., Ramirez-Duenas, M. G., et al. (2009). Low NKp30, NKp46 and NKG2D expression and reduced cytotoxic activity on NK cells in cervical cancer and precursor lesions. BMC Cancer 9:186. doi: 10.1186/1471-2407-9-186

Garrido, F., and Algarra, I. (2001). MHC antigens and tumor escape from immune surveillance. $A d v$. Cancer Res. 83, 117-158.

Garrido, F., Cabrera, T., Concha, A., Glew, S., Ruiz-Cabello, F., and Stern, P. L. (1993). Natural history of HLA expression during tumour development. Immunol. Today 14, 491-499.

Gavin, M., and Rudensky, A. (2003). Control of immune homeostasis by naturally arising regulatory $\mathrm{CD} 4^{+}$ T cells. Curr. Opin. Immunol. 15, 690-696.

Gavin, M. A., Rasmussen, J. P., Fontenot, J. D., Vasta, V., Manganiello, V. C., Beavo, J. A., et al. (2007). Foxp3-dependent programme of regulatory $\mathrm{T}$ cell differentiation. Nature 445, 771-775.

Gehrmann, M., Doss, B. T., Wagner, M., Zettlitz, K. A., Kontermann, R. E., Foulds, G., et al. (2011). A novel expression and purification system for the production of enzymatic and biologically active human granzyme B. J. Immunol. Methods 371, 8-17.

Gehrmann, M., Liebisch, G., Schmitz, G., Anderson, R., Steinem, C., De Maio, A., et al. (2008a). Tumor-specific Hsp70 plasma membrane localization is enabled by the glycophospholipid Gb3. PLoS ONE 3:e1925. doi: 10.1371/journal.pone.0001925

Gehrmann, M., Radons, J., Molls, M., and Multhoff, G. (2008b). The therapeutic implications of clinically applied modifiers of heat shock protein 70 (Hsp70) expression by tumor cells. Cell Stress Chaperones $13,1-10$.

Gehrmann, M., Pfister, K., Hutzler, P., Gastpar, R., Margulis, B., and Multhoff, G. (2002). Effects of antineoplastic agents on cytoplasmic and membrane-bound heat shock protein 70 (Hsp70) levels. Biol. Chem. 383, 1715-1725.

Gehrmann, M., Schilling, D., Molls, M., and Multhoff, G. (2010). Radiation induced stress proteins. Int. J. Clin. Pharmacol. Ther. 48, 492-493.
Gehrmann, M., Stangl, S., Kirschner, A., Foulds, G. A., Sievert, W., Doss, B. T., et al. (2012). Immunotherapeutic targeting of membrane hsp70-expressing tumors using recombinant human granzyme B. PLoS ONE 7:e41341. doi: 10.1371/journal.pone.0041341

Ghiringhelli, F., Menard, C., Terme, M., Flament, C., Taieb, J., Chaput, N., et al. (2005a). CD4 ${ }^{+} \mathrm{CD} 25^{+}$regulatory $\mathrm{T}$ cells inhibit natural killer cell functions in a transforming growth factor- $\beta$-dependent manner. J. Exp. Med. 202, 1075-1085.

Ghiringhelli, F., Puig, P. E., Roux, S., Parcellier, A., Schmitt, E., Solary, E., et al. (2005b). Tumor cells convert immature myeloid dendritic cells into TGF- $\beta$-secreting cells inducing $\mathrm{CD} 4{ }^{+} \mathrm{CD} 25^{+}$regulatory $\mathrm{T}$ cell proliferation. J. Exp. Med. 202, 919-929.

Golgher, D., Jones, E., Powrie, F., Elliott, T., and Gallimore, A. (2002). Depletion of $\mathrm{CD}_{2} 5^{+}$regulatory cells uncovers immune responses to shared murine tumor rejection antigens. Eur. J. Immunol. 32, 3267-3275.

Gooden, M., Lampen, M., Jordanova, E. S., Leffers, N., Trimbos, J. B., van der Burg, S. H., et al. (2011). HLA-E expression by gynecological cancers restrains tumor-infiltrating $\mathrm{CD}^{+} \mathrm{T}$ lymphocytes. Proc. Natl. Acad. Sci. U.S.A. 108, 10656-10661.

Graca, L. (2005). New tools to identify regulatory T cells. Eur. J. Immunol. 35, 1678-1680.

Grauer, O. M., Nierkens, S., Bennink, E., Toonen, L. W., Boon, L., Wesseling, P., et al. (2007). $\mathrm{CD}^{+}{ }^{+} \mathrm{FoxP}^{+}$regulatory $\mathrm{T}$ cells gradually accumulate in gliomas during tumor growth and efficiently suppress antiglioma immune responses in vivo. Int. J. Cancer 121, 95-105.

Gross, C., Hansch, D., Gastpar, R., and Multhoff, G. (2003a). Interaction of heat shock protein 70 peptide with NK cells involves the NK receptor CD94. Biol. Chem. 384, 267-279.

Gross, C., Schmidt-Wolf, I. G., Nagaraj, S., Gastpar, R., Ellwart, J., KunzSchughart, L. A., et al. (2003b). Heat shock protein 70-reactivity is associated with increased cell surface density of CD94/CD56 on primary natural killer cells. Cell Stress Chaperones 8, 348-360.

Groth, A., Kloss, S., von Strandmann, E. P., Koehl, U., and Koch, J. (2011). Mechanisms of tumor and viral immune escape from natural killer cell-mediated surveillance. J. Innate Immun. 3, 344-354.

Groux, H., O'Garra, A., Bigler, M., Rouleau, M., Antonenko, S., de
Vries, J. E., et al. (1997). A CD4 ${ }^{+}$Tcell subset inhibits antigen-specific T-cell responses and prevents colitis. Nature 389, 737-742.

Gupta, A. K., Cerniglia, G. J., Mick, R., Ahmed, M. S., Bakanauskas, V. J., Muschel, R. J., et al. (2003). Radiation sensitization of human cancer cells in vivo by inhibiting the activity of PI3K using LY294002. Int. J. Radiat. Oncol. Biol. Phys. 56, 846-853.

Gupta, A. K., McKenna, W. G., Weber, C. N., Feldman, M. D., Goldsmith, J. D., Mick, R., et al. (2002). Local recurrence in head and neck cancer: relationship to radiation resistance and signal transduction. Clin. Cancer Res. 8 , 885-892.

Guzhova, I., Kislyakova, K., Moskaliova, O., Fridlanskaya, I., Tytell, M., Cheetham, M., et al. (2001). In vitro studies show that Hsp70 can be released by glia and that exogenous Hsp70 can enhance neuronal stress tolerance. Brain Res. 914, 66-73.

Hallahan, D., Kuchibhotla, J., and Wyble, C. (1996). Cell adhesion molecules mediate radiationinduced leukocyte adhesion to the vascular endothelium. Cancer Res. 56, 5150-5155.

Handschel, J., Prott, F. J., Sunderkotter, C., Metze, D., Meyer, U., and Joos, U. (1999). Irradiation induces increase of adhesion molecules and accumulation of $\beta 2$-integrinexpressing cells in humans. Int. J. Radiat. Oncol. Biol. Phys. 45, 475-481.

Harrington, K. J., Karapanagiotou, E. M., Roulstone, V., Twigger, K. R., White, C. L., Vidal, L., et al. (2010). Two-stage phase I doseescalation study of intratumoral reovirus type 3 dearing and palliative radiotherapy in patients with advanced cancers. Clin. Cancer Res. 16, 3067-3077.

Harrington, K. J., Melcher, A., Vassaux, G., Pandha, H. S., and Vile, R. G. (2008). Exploiting synergies between radiation and oncolytic viruses. Curr. Opin. Mol. Ther. 10, 362-370.

Henderson, B., Calderwood, S. K., Coates, A. R., Cohen, I., van Eden, W., Lehner, T., et al. (2010). Caught with their PAMS down? The extracellular signalling actions of molecular chaperones are not due to microbial contaminants. Cell Stress Chaperones 15, 123-141.

Henderson, B., and Pockley, A. G. (2010). Molecular chaperones and protein folding catalysts as intercellular signaling regulators in immunity and inflammation. J. Leukoc. Biol. 88, 445-462.

Hingorani, M., White, C. L., Agrawal, V. K., Vidal, L., Melcher, A., and Harrington, K. J. (2007). Combining radiation and cancer gene therapy: a potential marriage of physical and biological targeting? Curr. Cancer Drug Targets 7, 389-409.

Holt, D., Ma, X., Kundu, N., and Fulton, A. (2011). Prostaglandin $\mathrm{E}_{2} \quad\left(\mathrm{PGE}_{2}\right)$ suppresses natural killer cell function primarily through the $\mathrm{PGE}_{2}$ receptor EP4. Cancer Immunol. Immunother. 60, 1577-1586.

Hong, H., Gu, Y., Zhang, H., Simon, A. K., Chen, X., Wu, C., et al. (2010). Depletion of $\mathrm{CD}^{+} \mathrm{CD} 25^{+}$regulatory $\mathrm{T}$ cells enhances natural killer $\mathrm{T}$ cell-mediated anti-tumour immunity in a murine mammary breast cancer model. Clin. Exp. Immunol. 159, 93-99.

Hurwitz, M. D., Kaur, P., Nagaraja, G. M., Bausero, M. A., Manola, J., and Asea, A. (2010). Radiation therapy induces circulating serum Hsp72 in patients with prostate cancer. Radiother. Oncol. 95, 350-358.

Iademarco, M. F., McQuillan, J. J., Rosen, G. D., and Dean, D. C. (1992). Characterization of the promoter for vascular cell adhesion molecule-1 (VCAM-1). J. Biol. Chem. 267, 16323-16329.

Izawa, S., Kono, K., Mimura, K., Kawaguchi, Y., Watanabe, M., Maruyama, T., et al. (2011). $\mathrm{H}_{2} \mathrm{O}_{2}$ production within tumor microenvironment inversely correlated with infiltration of CD56 ${ }^{\text {dim }} \mathrm{NK}$ cells in gastric and esophageal cancer: possible mechanisms of $\mathrm{NK}$ cell dysfunction. Cancer Immunol. Immunother. 60, 1801-1810.

Jacobs, J. F., Idema, A. J., Bol, K. F., Nierkens, S., Grauer, O. M., Wesseling, P., et al. (2009). Regulatory $\mathrm{T}$ cells and the PDL1/PD-1 pathway mediate immune suppression in malignant human brain tumors. Neuro Oncol. 11, 394-402.

Jacobs, J. F., Nierkens, S., Figdor, C. G., de Vries, I. J., and Adema, G. J. (2012). Regulatory T cells in melanoma: the final hurdle towards effective immunotherapy? Lancet Oncol. 13, e32-e42.

Jager, M. J., Hurks, H. M., Levitskaya, J., and Kiessling, R. (2002). HLA expression in uveal melanoma: there is no rule without some exception. Hum. Immunol. 63, 444-451.

Jimenez-Perez, M. I., Jave-Suarez, L. F., Ortiz-Lazareno, P. C., BravoCuellar, A., Gonzalez-Ramella, O., 
Aguilar-Lemarroy, A., et al. (2012). Cervical cancer cell lines expressing NKG2D-ligands are able to downmodulate the NKG2D receptor on NKL cells with functional implications. BMC Immunol. 13:7. doi: 10.1186/1471-2172-13-7

Johnsen, A. K., France, J., Nagy, N., Askew, D., Abdul-Karim, F. W., Gerson, S. L., et al. (2001). Systemic deficits in transporter for antigen presentation (TAP)-1 or proteasome subunit LMP2 have little or no effect on tumor incidence. Int. J. Cancer 91, 366-372.

Jones, E., Dahm-Vicker, M., Simon, A. K., Green, A., Powrie, F., Cerundolo, V., et al. (2002). Depletion of $\mathrm{CD} 25^{+}$regulatory cells results in suppression of melanoma growth and induction of autoreactivity in mice. Cancer Immun. 2, 1.

Jonuleit, H., Schmitt, E., Stassen, M., Tuettenberg, A., Knop, J., and Enk, A. H. (2001). Identification and functional characterization of human $\mathrm{CD} 4{ }^{+} \mathrm{CD} 25^{+} \mathrm{T}$ cells with regulatory properties isolated from peripheral blood. J. Exp. Med. 193, 1285-1294.

Karlhofer, F. M., Ribaudo, R. K., and Yokoyama, W. M. (1992). MHC class I alloantigen specificity of Ly49+ IL-2-activated natural killer cells. Nature 358, 66-70.

Kärre, K., Ljunggren, H. G., Piontek, G., and Kiessling, R. (1986). Selective rejection of $\mathrm{H}$-2-deficient lymphoma variants suggests alternative immune defence strategy. Nature 319, 675-678.

Kawai, T., and Akira, S. (2011). Tolllike receptors and their crosstalk with other innate receptors in infection and immunity. Immunity 34 , 637-650.

Kiessling, R., Klein, E., and Wigzell, H. (1975). "Natural" killer cells in the mouse. I. Cytotoxic cells with specificity for mouse Moloney leukemia cells. Specificity and distribution according to genotype. Eur. J. Immunol. 5, 112-117.

Kitamura, N., Murata, S., Ueki, T., Mekata, E., Reilly, R. T., Jaffee, E. M., et al. (2009). OX40 costimulation can abrogate Foxp $3^{+}$regulatory $\mathrm{T}$ cell-mediated suppression of antitumor immunity. Int. J. Cancer 125, 630-638.

Kitazawa, Y., Fujino, M., Wang, Q., Kimura, H., Azuma, M., Kubo, M., et al. (2007). Involvement of the programmed death1/programmed death-1 ligand pathway in $\mathrm{CD} 4{ }^{+} \mathrm{CD} 25^{+}$regulatory T-cell activity to suppress alloimmune responses. Transplantation $83,774-782$
Klein, O., Ebert, L. M., Nicholaou, T., Browning, J., Russell, S. E., Zuber, M., et al. (2009). Melan-Aspecific cytotoxic $\mathrm{T}$ cells are associated with tumor regression and autoimmunity following treatment with anti-CTLA-4. Clin. Cancer Res. 15, 2507-2513.

Knutson, K. L., Dang, Y., Lu, H., Lukas, J., Almand, B., Gad, E., et al. (2006). IL-2 immunotoxin therapy modulates tumor-associated regulatory $\mathrm{T}$ cells and leads to lasting immunemediated rejection of breast cancers in neu-transgenic mice. J. Immunol. 177, 84-91.

Kozin, S. V., Kamoun, W. S., Huang, Y., Dawson, M. R., Jain, R. K., and Duda, D. G. (2010). Recruitment of myeloid but not endothelial precursor cells facilitates tumor regrowth after local irradiation. Cancer Res. 70, 5679-5685.

Laheru, D., Lutz, E., Burke, J., Biedrzycki, B., Solt, S., Onners, B., et al. (2008). Allogeneic granulocyte macrophage colonystimulating factor-secreting tumor immunotherapy alone or in sequence with cyclophosphamide for metastatic pancreatic cancer: a pilot study of safety, feasibility, and immune activation. Clin. Cancer Res. 14, 1455-1463.

Langers, I., Renoux, V. M., Thiry, M., Delvenne, P., and Jacobs, N. (2012). Natural killer cells: role in local tumor growth and metastasis. Biologics 6, 73-82.

Le, D. T., and Jaffee, E. M. (2012). Regulatory T-cell modulation using cyclophosphamide in vaccine approaches: a current perspective. Cancer Res. 72, 3439-3444.

Lee, M. K., Moore, D. J., Jarrett, B. P. Lian, M. M., Deng, S., Huang, X., et al. (2004). Promotion of allograft survival by $\mathrm{CD} 4{ }^{+} \mathrm{CD} 25^{+}$regulatory $\mathrm{T}$ cells: evidence for in vivo inhibition of effector cell proliferation. J. Immunol. 172, 6539-6544.

Lee, W. C., Zhong, C., Qian, S., Wan, Y., Gauldie, J., Mi, Z., et al. (1998). Phenotype, function, and in vivo migration and survival of allogeneic dendritic cell progenitors genetically engineered to express TGF- $\beta$. Transplantation 66, 1810-1817.

Levings, M. K., Sangregorio, R., Galbiati, F., Squadrone, S., de Waal Malefyt, R., and Roncarolo, M. G. (2001a). IFN- $\alpha$ and IL-10 induce the differentiation of human type 1 $\mathrm{T}$ regulatory cells. J. Immunol. 166, 5530-5539.

Levings, M. K., Sangregorio, R., and Roncarolo, M. G. (2001b). Human $\mathrm{CD} 25^{+} \mathrm{CD} 4{ }^{+} \mathrm{T}$ regulatory cells suppress naive and memory $\mathrm{T}$ cell proliferation and can be expanded in vitro without loss of function. J. Exp. Med. 193, 1295-1302.

Li, X., Ye, D. F., Xie, X., Chen, H. Z., and Lu, W. G. (2005). Proportion of $\mathrm{CD} 4{ }^{+} \mathrm{CD} 25^{+}$regulatory $\mathrm{T}$ cell is increased in the patients with ovarian carcinoma. Cancer Invest. 23 399-403.

Lindau, D., Gielen, P., Kroesen, M. Wesseling, P., and Adema, G. J. (2013). The immunosuppressive tumor network: MDSCs, Tregs and NKT cells. Immunology 138 , 105-115.

Liu, H., Komai-Koma, M., Xu, D., and Liew, F. Y. (2006a). Toll-like receptor 2 signaling modulates the functions of $\mathrm{CD} 4{ }^{+} \mathrm{CD} 25^{+}$regulatory $\mathrm{T}$ cells. Proc. Natl. Acad. Sci. U.S.A. 103, 7048-7053.

Liu, W., Putnam, A. L., Xu-Yu, Z., Szot, G. L., Lee, M. R., Zhu S., et al. (2006b). CD127 expression inversely correlates with FoxP3 and suppressive function of human CD4 ${ }^{+}$T reg cells. J. Exp. Med. 203 1701-1711.

Liu, V. C., Wong, L. Y., Jang, T., Shah, A. H., Park, I., Yang, X., et al. (2007). Tumor evasion of the immune system by converting $\mathrm{CD} 4^{+} \mathrm{CD} 25^{-} \mathrm{T}$ cells into $\mathrm{CD} 4{ }^{+} \mathrm{CD} 25^{+} \mathrm{T}$ regulatory cells: role of tumor-derived TGF- $\beta$. J. Immunol. 178, 2883-2892.

Liyanage, U. K., Goedegebuure, P. S., Moore, T. T., Viehl, C. T., Moo-Young, T. A., Larson, J. W. et al. (2006). Increased prevalence of regulatory $\mathrm{T}$ cells (Treg) is induced by pancreas adenocarcinoma. J. Immunother. 29, 416-424.

Liyanage, U. K., Moore, T. T., Joo, H. G., Tanaka, Y., Herrmann, V., Doherty, G., et al. (2002). Prevalence of regulatory $\mathrm{T}$ cells is increased in peripheral blood and tumor microenvironment of patients with pancreas or breast adenocarcinoma. J. Immunol. 169, 2756-2761.

Ljunggren, H. G., and Kärre, K (1990). In search of the 'missing self': MHC molecules and NK cell recognition. Immunol. Today 11 , 237-244.

Loke, P., and Allison, J. P. (2003) PD-L1 and PD-L2 are differentially regulated by Th1 and Th2 cells. Proc. Natl. Acad. Sci. U.S.A. 100, 5336-5341

Lugade, A. A., Moran, J. P., Gerber, S. A., Rose, R. C., Frelinger, J. G., and Lord, E. M. (2005). Local radiation therapy of B16 melanoma tumors increases the generation of tumor antigen-specific effector cells that traffic to the tumor. J. Immunol. 174 7516-7523.
Machiels, J. P., Reilly, R. T., Emens, L. A., Ercolini, A. M., Lei, R. Y., Weintraub, D., et al. (2001). Cyclophosphamide, doxorubicin, and paclitaxel enhance the antitumor immune response of granulocyte/macrophagecolony stimulating factor-secreting whole-cell vaccines in HER-2/neu tolerized mice. Cancer Res. 61, 3689-3697.

Madjd, Z., Spendlove, I., Pinder, S. E., Ellis, I. O., and Durrant, L. G. (2005). Total loss of MHC class I is an independent indicator of good prognosis in breast cancer. Int. J. Cancer 117, 248-255.

Mahnke, K., Bedke, T., and Enk, A. H. (2007a). Regulatory conversation between antigen presenting cells and regulatory $\mathrm{T}$ cells enhance immune suppression. Cell. Immunol. 250, 1-13.

Mahnke, K., Schonfeld, K., Fondel, S., Ring, S., Karakhanova, S., Wiedemeyer, K., et al. (2007b). Depletion of $\mathrm{CD}^{+}{ }^{+} \mathrm{CD} 25^{+}$human regulatory $\mathrm{T}$ cells in vivo: kinetics of Treg depletion and alterations in immune functions in vivo and in vitro. Int. J. Cancer 120, 2723-2733.

Mailloux, A. W., and Young, M. R. (2009). NK-dependent increases in CCL22 secretion selectively recruits regulatory $\mathrm{T}$ cells to the tumor microenvironment. J. Immunol. 182, 2753-2765.

Maker, A. V., Attia, P., and Rosenberg, S. A. (2005). Analysis of the cellular mechanism of antitumor responses and autoimmunity in patients treated with CTLA-4 blockade. J. Immunol. 175, 7746-7754.

Mambula, S. S., and Calderwood, S. K. (2006a). Heat induced release of Hsp70 from prostate carcinoma cells involves both active secretion and passive release from necrotic cells. Int. J. Hyperthermia 22, 575-585.

Mambula, S. S., and Calderwood, S. K. (2006b). Heat shock protein 70 is secreted from tumor cells by a nonclassical pathway involving lysosomal endosomes. J. Immunol. 177, 7849-7857.

Mamessier, E., Sylvain, A., Bertucci, F., Castellano, R., Finetti, P. Houvenaeghel, G., et al. (2011a). Human breast tumor cells induce self-tolerance mechanisms to avoid NKG2D-mediated and DNAMmediated NK cell recognition. Cancer Res. 71, 6621-6632.

Mamessier, E., Sylvain, A., Thibult, M. L., Houvenaeghel, G., Jacquemier, J., Castellano, R., et al. (2011b). Human breast cancer cells enhance 
self tolerance by promoting evasion from NK cell antitumor immunity. J. Clin. Invest. 121, 3609-3622.

Manda, K., Glasow, A., Paape, D., and Hildebrandt, G. (2012). Effects of ionizing radiation on the immune system with special emphasis on the interaction of dendritic and T cells. Front. Oncol. 2:102. doi: 10.3389/fonc. 2012.00102

Mandapathil, M., Szczepanski, M. J., Szajnik, M., Ren, J., Jackson, E. K., Johnson, J. T., et al. (2010). Adenosine and prostaglandin E2 cooperate in the suppression of immune responses mediated by adaptive regulatory $\mathrm{T}$ cells. J. Biol. Chem. 285, 27571-27580.

Marincola, F. M., Jaffee, E. M., Hicklin, D. J., and Ferrone, S. (2000). Escape of human solid tumors from $\mathrm{T}$ cell recognition: molecular mechanisms and functional significance. Adv. Immunol. 74, 181-273.

Martinović, K. M., Konjević, G., Babović, N., and Inić, M. (2011). The stage dependent changes in NK cell activity and the expression of activating and inhibitory NK cell receptors in melanoma patients. J. Surg. Res. 171, 637-649.

Matsumura, S., and Demaria, S. (2010). Up-regulation of the proinflammatory chemokine CXCL16 is a common response of tumor cells to ionizing radiation. Radiat. Res. 173, 418-425.

Matsumura, S., Wang, B., Kawashima, N., Braunstein, S., Badura, M., Cameron, T. O., et al. (2008). Radiation-induced CXCL16 release by breast cancer cells attracts effector T cells. J. Immunol. 181, 3099-3107.

McHugh, R. S., and Shevach, E. M. (2002). Cutting edge: depletion of $\mathrm{CD} 4{ }^{+} \mathrm{CD} 25^{+}$regulatory $\mathrm{T}$ cells is necessary, but not sufficient, for induction of organ-specific autoimmune disease. J. Immunol. 168, 5979-5983.

McKenna, W. G., Muschel, R. J., Gupta, A. K., Hahn, S. M., and Bernhard, E. J. (2003). The RAS signal transduction pathway and its role in radiation sensitivity. Oncogene 22, 5866-5875.

Mencin, A., Kluwe, J., and Schwabe, R. F. (2009). Toll-like receptors as targets in chronic liver diseases. Gut 58, 704-720.

Ménétrier-Caux, C., Curiel, T., Faget, J., Manuel, M., Caux, C., and Zou, W. (2012). Targeting regulatory $\mathrm{T}$ cells. Target Oncol. 7, 15-28.

Menon, A. G., Morreau, H., Tollenaar, R. A., Alphenaar, E., Van Puijenbroek, M., Putter, H., et al. (2002). Down-regulation of HLA-A expression correlates with a better prognosis in colorectal cancer patients. Lab. Invest. 82, 1725-1733.

Miyake, K., Yamashita, Y., Ogata, M., Sudo, T., and Kimoto, M. (1995). RP105, a novel B cell surface molecule implicated in $B$ cell activation, is a member of the leucine-rich repeat protein family. J. Immunol. 154, 3333-3340.

Molenkamp, B. G., van Leeuwen, P. A., Meijer, S., Sluijter, B. J., Wijnands, P. G., Baars, A., et al. (2007). Intradermal $\mathrm{CpG}-\mathrm{B}$ activates both plasmacytoid and myeloid dendritic cells in the sentinel lymph node of melanoma patients. Clin. Cancer Res. 13, 2961-2969.

Moon, H. W., Kim, B. H., Park, C. M., Hur, M., Yun, Y. M., Kim, S. Y., et al. (2011). CD $4^{+} \mathrm{CD} 25^{\text {high }}$ FoxP $3^{+}$regulatory T-cells in hematologic diseases. Korean J. Lab. Med. 31, 231-237.

Moretta, A., Vitale, M., Bottino, C., Orengo, A. M., Morelli, L., Augugliaro, R., et al. (1993). P58 molecules as putative receptors for major histocompatibility complex (MHC) class I molecules in human natural killer (NK) cells. Anti-p58 antibodies reconstitute lysis of MHC class I-protected cells in NK clones displaying different specificities. J. Exp. Med. 178, 597-604.

Mori, N., and Prager, D. (1996). Transactivation of the interleukinlalpha promoter by human $\mathrm{T}$ cell leukemia virus type I and type II Tax proteins. Blood 87 3410-3417.

Motoyoshi, Y., Kaminoda, K., Saitoh, O., Hamasaki, K., Nakao, K., Ishii, N., et al. (2006). Different mechanisms for anti-tumor effects of lowand high-dose cyclophosphamide. Oncol. Rep. 16, 141-146.

Mougiakakos, D., Johansson, C. C., Trocme, E., All-Ericsson, C., Economou, M. A., Larsson, O., et al. (2010). Intratumoral forkhead box P3-positive regulatory $\mathrm{T}$ cells predict poor survival in cyclooxygenase-2-positive uveal melanoma. Cancer 116, 2224-2233.

Multhoff, G. (2007). Heat shock protein 70 (Hsp70): membrane location, export and immunological relevance. Methods 43, 229-237.

Multhoff, G. (2009). Activation of natural killer cells by heat shock protein 70. 2002. Int. J. Hyperthermia 25 , 169-175.

Multhoff, G., Botzler, C., Jennen, L., Schmidt, J., Ellwart, J., and Issels, R. (1997). Heat shock protein 72 on tumor cells: a recognition structure for natural killer cells. J. Immunol. 158, 4341-4350.

Multhoff, G., Botzler, C., Wiesnet, M., Muller, E., Meier, T., Wilmanns, W. et al. (1995). A stress-inducible 72 $\mathrm{kDa}$ heat-shock protein (HSP72) is expressed on the surface of human tumor cells, but not on normal cells. Int. J. Cancer 61, 272-279.

Multhoff, G., and Hightower, L. E. (1996). Cell surface expression of heat shock proteins and the immune response. Cell Stress Chaperones 1, 167-176.

Multhoff, G., Pfister, K., Gehrmann, M., Hantschel, M., Gross, C. Hafner, M., et al. (2001). A 14-mer Hsp70 peptide stimulates natural killer (NK) cell activity. Cell Stress Chaperones 6, 337-344.

Multhoff, G., and Radons, J. (2012). Radiation, inflammation, and immune responses in cancer. Front. Oncol. 2:58. doi: 10.3389/fonc. 2012.00058

Nagler, A., Lanier, L. L., Cwirla, S., and Phillips, J. H. (1989). Comparative studies of human FcRIII-positive and negative natural killer cells. J. Immunol. 143, 3183-3191.

Nelson, B. H. (2004). IL-2, regulatory T cells, and tolerance. J. Immunol. 172, 3983-3988.

Oberg, H. H., Juricke, M., Kabelitz, D., and Wesch, D. (2011). Regulation of T cell activation by TLR ligands. Eur. J. Cell Biol. 90, 582-592.

Onizuka, S., Tawara, I., Shimizu, J., Sakaguchi, S., Fujita, T., and Nakayama, E. (1999). Tumor rejection by in vivo administration of anti-CD25 (interleukin-2 receptor alpha) monoclonal antibody. Cancer Res. 59, 3128-3133.

Ozao-Choy, J., Ma, G., Kao, J., Wang, G. X., Meseck, M., Sung, M., et al. (2009). The novel role of tyrosine kinase inhibitor in the reversal of immune suppression and modulation of tumor microenvironment for immune-based cancer therapies. Cancer Res. 69, 2514-2522.

Peng, G., Guo, Z., Kiniwa, Y., Voo, K. S., Peng, W., Fu, T., et al. (2005). Tolllike receptor 8-mediated reversal of $\mathrm{CD}^{+}{ }^{+}$regulatory $\mathrm{T}$ cell function. Science 309, 1380-1384.

Piconese, S., Valzasina, B., and Colombo, M. P. (2008). OX40 triggering blocks suppression by regulatory $\mathrm{T}$ cells and facilitates tumor rejection. J. Exp. Med. 205, 825-839.

Pockley, A. G. (2003). Heat shock proteins and their role as regulators of the immune response. Lancet 362 , 469-476.
Pockley, A. G., Bulmer, J., Hanks, B. M., and Wright, B. H. (1999). Identification of human heat shock protein 60 (Hsp60) and anti-Hsp60 antibodies in the peripheral circulation of normal individuals. Cell Stress Chaperones 4, 29-35.

Pockley, A. G., Shepherd, J., and Corton, J. (1998). Detection of heat shock protein 70 (Hsp70) and antiHsp70 antibodies in the serum of normal individuals. Immunol. Invest. 27, 367-377.

Pockley, A. G., Wu, R., Lemne, C., Kiessling, R., de Faire, U., and Frostegård, J. (2000). Circulating heat shock protein 60 is associated with early cardiovascular disease. Hypertension 36, 303-307.

Prestwich, R. J., Harrington, K. J., Pandha, H. S., Vile, R. G., Melcher, A. A., and Errington, F. (2008). Oncolytic viruses: a novel form of immunotherapy. Expert Rev. Anticancer Ther. 8, 1581-1588.

Raimondi, G., Turner, M. S., Thomson, A. W., and Morel, P. A. (2007). Naturally occurring regulatory $\mathrm{T}$ cells: recent insights in health and disease. Crit. Rev. Immunol. 27, 61-95.

Ralph, C., Elkord, E., Burt, D. J., O’Dwyer, J. F., Austin, E. B., Stern, P. L., et al. (2010). Modulation of lymphocyte regulation for cancer therapy: a phase II trial of tremelimumab in advanced gastric and esophageal adenocarcinoma. Clin. Cancer Res. 16, 1662-1672.

Ramnath, N., Tan, D., Li, Q., Hylander, B. L., Bogner, P., Ryes, L., et al. (2006). Is downregulation of MHC class I antigen expression in human non-small cell lung cancer associated with prolonged survival? Cancer Immunol. Immunother. 55, 891-899.

Rea, I. M., McNerlan, S., and Pockley, A. G. (2001). Serum heat shock protein and anti-heat shock protein antibody levels in aging. Exp. Gerontol. 36, 341-352.

Rech, A. J., and Vonderheide, R. H. (2009). Clinical use of anti-CD25 antibody daclizumab to enhance immune responses to tumor antigen vaccination by targeting regulatory T cells. Ann. N.Y. Acad. Sci. 1174, 99-106.

Reits, E. A., Hodge, J. W., Herberts, C. A., Groothuis, T. A., Chakraborty, M., Wansley, E. K., et al. (2006). Radiation modulates the peptide repertoire, enhances MHC class I expression, and induces successful antitumor immunotherapy. J. Exp. Med. 203, 1259-1271.

Restifo, N. P. (1996). The new vaccines: building viruses that elicit 
antitumor immunity. Curr. Opin. Immunol. 8, 658-663.

Rödel, F., Frey, B., Manda, K., Hildebrandt, G., Hehlgans, S., Keilholz, L., et al. (2012). Immunomodulatory properties and molecular effects in inflammatory diseases of low-dose x-irradiation. Front. Oncol. 2:120. doi: $10.3389 /$ fonc. 2012.00120

Roncarolo, M. G., Gregori, S., Battaglia, M., Bacchetta, R., Fleischhauer, K., and Levings, M. K. (2006). Interleukin-10-secreting type 1 regulatory $\mathrm{T}$ cells in rodents and humans. Immunol. Rev. 212, 28-50.

Rubner, Y., Wunderlich, R., Ruhle, P. F., Kulzer, L., Werthmoller, N., Frey, B., et al. (2012). How does ionizing irradiation contribute to the induction of anti-tumor immunity? Front. Oncol. 2:75. doi: 10.3389/fonc.2012.00075

Rudge, G., Barrett, S. P., Scott, B., and van Driel, I. R. (2007). Infiltration of a mesothelioma by IFN- $\gamma$ producing cells and tumor rejection after depletion of regulatory $\mathrm{T}$ cells. J. Immunol. 178, 4089-4096.

Russell, J. S., Lang, F. F., Huet, T., Janicot, M., Chada, S., Wilson, D. R., et al. (1999). Radiosensitization of human tumor cell lines induced by the adenovirus-mediated expression of an anti-Ras single-chain antibody fragment. Cancer Res. 59, 5239-5244.

Saito, H., Osaki, T., and Ikeguchi, M. (2012). Decreased NKG2D expression on NK cells correlates with impaired NK cell function in patients with gastric cancer. Gastric Cancer 15, 27-33.

Sakaguchi, S. (2004). Naturally arising $\mathrm{CD}^{+}$regulatory $\mathrm{T}$ cells for immunologic self-tolerance and negative control of immune responses. Annu. Rev. Immunol. 22, 531-562.

Sakaguchi, S. (2011). Regulatory T cells: history and perspective. Methods Mol. Biol. 707, 3-17.

Sakaguchi, S., Sakaguchi, N., Asano, M., Itoh, M., and Toda, M. (1995). Immunologic self-tolerance maintained by activated $\mathrm{T}$ cells expressing IL-2 receptor alphachains (CD25). Breakdown of a single mechanism of self-tolerance causes various autoimmune diseases. J. Immunol. 155, 1151-1164.

Savage, P. A., Malchow, S., and Leventhal, D. S. (2013). Basic principles of tumor-associated regulatory $\mathrm{T}$ cell biology. Trends Immunol. 34, 33-40.

Schilling, D., Gehrmann, M., Steinem, C., De Maio, A., Pockley, A. G.,
Abend, M., et al. (2009). Binding of heat shock protein 70 to extracellular phosphatidylserine promotes killing of normoxic and hypoxic tumor cells. FASEB J. 23, 2467-2477.

Schindler, U., and Baichwal, V. R. (1994). Three NF-kappa B binding sites in the human E-selectin gene required for maximal tumor necrosis factor alpha-induced expression. Mol. Cell. Biol. 14, 5820-5831.

Schmetterer, K. G., Neunkirchner, A., and Pickl, W. F. (2012). Naturally occurring regulatory $\mathrm{T}$ cells: markers, mechanisms, and manipulation. FASEB J. 26, 2253-2276.

Schmid, T. E., and Multhoff, G. (2012). Non-targeted effects of photon and particle irradiation and the interaction with the immune system. Front. Oncol. 2:80. doi: 10.3389/fonc. 2012.00080

Schmidtner, J., Distel, L. V., Ott, O. J., Nkenke, E., Sprung, C. N., Fietkau, R., et al. (2009). Hyperthermia and irradiation of head and neck squamous cancer cells causes migratory profile changes of tumour infiltrating lymphocytes. Int. J. Hyperthermia 25, 347-354.

Schuler, P. J., Borger, V., Bolke, E., Habermehl, D., Matuschek, C., Wild, C. A., et al. (2011). Dendritic cell generation and $\mathrm{CD}^{+}{ }^{+} \mathrm{CD} 25^{\text {high }} \mathrm{FOXP}^{+}$regulatory $\mathrm{T}$ cells in human head and neck carcinoma during radiochemotherapy. Eur. J. Med. Res. 16, 57-62.

Seddiki, N., Santner-Nanan, B., Martinson, J., Zaunders, J., Sasson, S., Landay, A., et al. (2006). Expression of interleukin (IL)-2 and IL-7 receptors discriminates between human regulatory and activated T cells. J. Exp. Med. 203, 1693-1700.

Shakhov, A. N., Collart, M. A., Vassalli, P., Nedospasov, S. A., and Jongeneel, C. V. (1990). Kappa B-type enhancers are involved in lipopolysaccharide-mediated transcriptional activation of the tumor necrosis factor alpha gene in primary macrophages. J. Exp. Med. $171,35-47$.

Shan, Y. X., Jin, S. Z., Liu, X. D., Liu, Y., and Liu, S. Z. (2007). Ionizing radiation stimulates secretion of pro-inflammatory cytokines: doseresponse relationship, mechanisms and implications. Radiat. Environ. Biophys 46, 21-29.

Shevach, E. M. (2002). CD $4{ }^{+} \mathrm{CD} 25^{+}$ suppressor $\mathrm{T}$ cells: more questions than answers. Nat. Rev. Immunol. 2, 389-400.
Shevach, E. M. (2011). Biological functions of regulatory T cells. $A d v$. Immunol. 112, 137-176.

Shiao, S. L., and Coussens, L. M. (2010). The tumor-immune microenvironment and response to radiation therapy. J. Mammary Gland Biol. Neoplasia 15, 411-421.

Shimizu, J., Yamazaki, S., and Sakaguchi, S. (1999). Induction of tumor immunity by removing $\mathrm{CD} 25^{+} \mathrm{CD} 4^{+} \mathrm{T}$ cells: a common basis between tumor immunity and autoimmunity. J. Immunol. 163 5211-5218.

Shin, B. K., Wang, H., Yim, A. M., Le Naour, F., Brichory, F., Jang, J. H., et al. (2003). Global profiling of the cell surface proteome of cancer cells uncovers an abundance of proteins with chaperone function. J. Biol. Chem. 278, 7607-7616.

Song, B., Song, W. G., Li, Z. J., Xu, Z. F., Wang, X. W., Wang, C. X., et al. (2011). Effect of HMGB1 silencing on cell proliferation, invasion and apoptosis of MGC-803 gastric cancer cells. Cell Biochem. Funct. 30, 11-17.

Stangl, S., Gehrmann, M., Dressel, R., Alves, F., Dullin, C., Themelis, G., et al. (2010). In vivo imaging of CT26 mouse tumors by using cmHsp70.1 monoclonal antibody. J. Cell. Mol. Med. 15, 874-887.

Stangl, S., Gehrmann, M., Riegger, J., Kuhs, K., Riederer, I., Sievert, W., et al. (2011). Targeting membrane heat-shock protein 70 (Hsp70) on tumors by cmHsp70.1 antibody. Proc. Natl. Acad. Sci. U.S.A. 108, 733-738.

Steinbrink, K., Jonuleit, H., Muller, G., Schuler, G., Knop, J., and Enk, A. H. (1999). Interleukin-10-treated human dendritic cells induce a melanoma-antigen-specific anergy in $\mathrm{CD}^{+}{ }^{+} \mathrm{T}$ cells resulting in a failure to lyse tumor cells. Blood 93, 1634-1642.

Steinbrink, K., Wolfl, M., Jonuleit, H., Knop, J., and Enk, A. H. (1997) Induction of tolerance by IL-10treated dendritic cells. J. Immunol. 159, 4772-4780.

Steitz, J., Bruck, J., Lenz, J., Knop, J. and Tuting, T. (2001). Depletion of $\mathrm{CD} 25^{+} \mathrm{CD} 4{ }^{+} \mathrm{T}$ cells and treatment with tyrosinase-related protein 2transduced dendritic cells enhance the interferon alpha-induced, $\mathrm{CD}^{+}$T-cell-dependent immune defense of B16 melanoma. Cancer Res. 61, 8643-8646.

Stobo, J. D., Rosenthal, A. S., and Paul, W. E. (1973). Functional heterogeneity of murine lymphoid cells. V. Lymphocytes lacking detectable surface theta or immunoglobulin determinants. J. Exp. Med. 138, 71-88.

Stocki, P., Wang, X. N., and Dickinson, A. M. (2012). Inducible heat shock protein 70 reduces $\mathrm{T}$ cell responses and stimulatory capacity of monocyte-derived dendritic cells. J. Biol. Chem. 287, 12387-12394.

Strauss, L., Bergmann, C., Szczepanski, M., Gooding, W., Johnson, J. T., and Whiteside, T. L. (2007). A unique subset of $\mathrm{CD} 4^{+} \mathrm{CD} 25^{\text {high }} \mathrm{Foxp}^{+}{ }^{+} \mathrm{T}$ cells secreting interleukin-10 and transforming growth factor-betal mediates suppression in the tumor microenvironment. Clin. Cancer Res. 13, 4345-4354.

Suri-Payer, E., Amar, A. Z., Thornton, A. M., and Shevach, E. M. (1998). $\mathrm{CD} 4{ }^{+} \mathrm{CD} 25^{+} \mathrm{T}$ cells inhibit both the induction and effector function of autoreactive $T$ cells and represent a unique lineage of immunoregulatory cells. J. Immunol. 160, 1212-1218.

Sutmuller, R. P., van Duivenvoorde, L. M., van Elsas, A., Schumacher, T. N., Wildenberg, M. E., Allison, J. P., et al. (2001). Synergism of cytotoxic $\mathrm{T}$ lymphocyte-associated antigen 4 blockade and depletion of $\mathrm{CD}_{25} 5^{+}$regulatory $\mathrm{T}$ cells in antitumor therapy reveals alternative pathways for suppression of autoreactive cytotoxic T lymphocyte responses. J. Exp. Med. 194, 823-832.

Suzuki, Y., Mimura, K., Yoshimoto, Y., Watanabe, M., Ohkubo, Y., Izawa, S., et al. (2012). Immunogenic tumor cell death induced by chemoradiotherapy in patients with esophageal squamous cell carcinoma. Cancer Res. 72, 3967-3976.

Thompson, R. H., Dong, H., Lohse, C. M., Leibovich, B. C., Blute, M. L. Cheville, J. C., et al. (2007). PD1 is expressed by tumor-infiltrating immune cells and is associated with poor outcome for patients with renal cell carcinoma. Clin. Cancer Res. 13, 1757-1761.

Topalian, S. L., Drake, C. G., and Pardoll, D. M. (2012a). Targeting the PD-1/B7-H1(PD-L1) pathway to activate anti-tumor immunity. Curr. Opin. Immunol. 24, 207-212.

Topalian, S. L., Hodi, F. S., Brahmer, J. R., Gettinger, S. N., Smith, D. C. McDermott, D. F., et al. (2012b). Safety, activity, and immune correlates of anti-PD-1 antibody in cancer. N. Engl. J. Med. 366, 2443-2454

Twigger, K., Vidal, L., White, C. L., De Bono, J. S., Bhide, S., Coffey, M., et al. (2008). Enhanced in vitro 
and in vivo cytotoxicity of combined reovirus and radiotherapy. Clin. Cancer Res. 14, 912-923.

van Maren, W. W., Jacobs, J. F., de Vries, I. J., Nierkens, S., and Adema, G. J. (2008). Toll-like receptor signalling on Tregs: to suppress or not to suppress? Immunology 124, 445-452.

Viehl, C. T., Moore, T. T., Liyanage, U. K., Frey, D. M., Ehlers, J. P., Eberlein, T. J., et al. (2006). Depletion of $\mathrm{CD} 4{ }^{+} \mathrm{CD} 25^{+}$regulatory $\mathrm{T}$ cells promotes a tumor-specific immune response in pancreas cancerbearing mice. Ann. Surg. Oncol. 13, 1252-1258.

Vigouroux, S., Yvon, E., Biagi, E., and Brenner, M. K. (2004). Antigeninduced regulatory $\mathrm{T}$ cells. Blood 104, 26-33.

Vivier, E., Nunes, J. A., and Vely, F. (2004). Natural killer cell signaling pathways. Science 306, 1517-1519.

Vivier, E., Raulet, D. H., Moretta, A., Caligiuri, M. A., Zitvogel, L., Lanier, L. L., et al. (2011). Innate or adaptive immunity? The example of natural killer cells. Science 331, 44-49.

Vivier, E., Tomasello, E., Baratin, M., Walzer, T., and Ugolini, S. (2008). Functions of natural killer cells. Nat. Immunol. 9, 503-510.

Waldmann, H., Graca, L., Cobbold, S., Adams, E., Tone, M., and Tone, Y. (2004). Regulatory T cells and organ transplantation. Semin. Immunol. $16,119-126$

Wan, Y. Y., and Flavell, R. A. (2007). Regulatory T-cell functions are subverted and converted owing to attenuated Foxp3 expression. Nature 445, 766-770.

Wang, M. H., Grossmann, M. E., and Young, C. Y. (2004). Forced expression of heat-shock protein 70 increases the secretion of Hsp70 and provides protection against tumour growth. Br. J. Cancer 90, 926-931.

Wang, W., Lau, R., Yu, D., Zhu, W., Korman, A., and Weber, J. (2009). PD1 blockade reverses the suppression of melanoma antigenspecific CTL by $\mathrm{CD} 4{ }^{+} \mathrm{CD} 25^{\mathrm{Hi}}$ regulatory $\mathrm{T}$ cells. Int. Immunol. 21 , 1065-1077.

Whiteside, T. L. (2012). What are regulatory $\mathrm{T}$ cells (Treg) regulating in cancer and why? Semin. Cancer Biol. $22,327-334$.

Wickremasinghe, M. I., Thomas, L. H., O'Kane, C. M., Uddin, J., and Friedland, J. S. (2004). Transcriptional mechanisms regulating alveolar epithelial cell-specific CCL5 secretion in pulmonary tuberculosis. J. Biol. Chem. 279, 27199-27210.

Wolchok, J. D., Weber, J. S., Hamid, O., Lebbe, C., Maio, M., Schadendorf, D., et al. (2010). Ipilimumab efficacy and safety in patients with advanced melanoma: a retrospective analysis of HLA subtype from four trials. Cancer Immun. 10, 9.

Wolf, A. M., Wolf, D., Steurer, M., Gastl, G., Gunsilius, E., and GrubeckLoebenstein, B. (2003). Increase of regulatory $\mathrm{T}$ cells in the peripheral blood of cancer patients. Clin. Cancer Res. 9, 606-612.
Wood, K. J., and Sakaguchi, S. (2003). Regulatory $\mathrm{T}$ cells in transplantation tolerance. Nat. Rev. Immunol. 3 , 199-210.

$\mathrm{Xu}, \mathrm{T}$, Duan, Q., Wang, G., and Hu, B. (2011). $\mathrm{CD}^{+} \mathrm{CD} 25^{\text {high }}$ regulatory $\mathrm{T}$ cell numbers and FOXP3 mRNA expression in patients with advanced esophageal cancer before and after chemotherapy. Cell Biochem. Biophys. 61, 389-392.

Yamagiwa, S., Gray, J. D., Hashimoto, S., and Horwitz, D. A. (2001) A role for TGF- $\beta$ in the generation and expansion of $\mathrm{CD} 4^{+} \mathrm{CD} 25^{+}$ regulatory $\mathrm{T}$ cells from human peripheral blood. J. Immunol. 166, 7282-7289.

Yuan, X. L., Chen, L., Zhang, T. T., Ma, Y. H., Zhou, Y. L., Zhao, Y., et al. (2011). Gastric cancer cells induce human $\mathrm{CD}^{+}{ }^{+}$Foxp $3^{+}$regulatory $\mathrm{T}$ cells through the production of TGF-betal. World J. Gastroenterol. 17, 2019-2027.

Zaidi, S. H., Huddart, R. A., and Harrington, K. J. (2009). Novel targeted radiosensitisers in cancer treatment. Curr. Drug Discov. Technol. 6, 103-134.

Zhang, Y., Luo, F., Cai, Y., Liu, N., Wang, L., Xu, D., et al. (2011). TLR1/TLR2 agonist induces tumor regression by reciprocal modulation of effector and regulatory $\mathrm{T}$ cells. J. Immunol. 186, 1963-1969.

Zheng, P., Sarma, S., Guo, Y., and Liu, Y. (1999). Two mechanisms for tumor evasion of preexisting cytotoxic T-cell responses: lessons from recurrent tumors. Cancer Res. 59, 3461-3467.
Zhou, G., and Levitsky, H. I. (2007). Natural regulatory $\mathrm{T}$ cells and de novo-induced regulatory $\mathrm{T}$ cells contribute independently to tumor-specific tolerance. J. Immunol. 178, 2155-2162.

Zou, W. (2005). Immunosuppressive networks in the tumour environment and their therapeutic relevance. Nat. Rev. Cancer 5, 263-274.

Conflict of Interest Statement: The authors declare that the research was conducted in the absence of any commercial or financial relationships that could be construed as a potential conflict of interest.

Received: 22 October 2012; paper pending published: 05 November 2012; accepted: 15 January 2013; published online: 01 February 2013.

Citation: Foulds GA, Radons J, Kreuzer M, Multhoff $G$ and Pockley AG (2013) Influence of tumors on protective antitumor immunity and the effects of irradiation. Front. Oncol. 3:14. doi: 10.3389/ fonc.2013.00014

This article was submitted to Frontiers in Molecular and Cellular Oncology, a specialty of Frontiers in Oncology.

Copyright (c) 2013 Foulds, Radons, Kreuzer, Multhoff and Pockley. This is an open-access article distributed under the terms of the Creative Commons Attribution License, which permits use, distribution and reproduction in other forums, provided the original authors and source are credited and subject to any copyright notices concerning any thirdparty graphics etc. 